\title{
Quantum-Chemical Design of Molecular Structures of Tetra-, Penta- and Hexanuclear Metal Clusters Containing Aluminum and $3 d$-Element Atoms
}

\author{
Oleg V. Mikhailov ${ }^{1, *(1)}$ and Denis V. Chachkov ${ }^{2}$ \\ 1 Department of Analytical Chemistry, Certification and Quality Management, Kazan National Research \\ Technological University, K. Marx Street 68, 420015 Kazan, Russia \\ 2 Kazan Department of Joint Supercomputer Center of Russian Academy of Sciences - Branch of Federal \\ Scientific Center "Scientific Research Institute for System Analysis of the RAS", Lobachevskii Street 2/31, \\ 420111 Kazan, Russia; de2005c@gmail.com \\ * Correspondence: olegmkhlv@gmail.com
}

Received: 7 March 2020; Accepted: 13 April 2020; Published: 15 April 2020

check for updates

\begin{abstract}
Various data on the structural and thermodynamic characteristics of polynuclear metal clusters containing atoms of aluminum and various $d$-elements with the general formula $\mathrm{Al}_{n} \mathrm{M}_{m}$ where $(n+m)$ is 4,5 , or 6 , and which can be precursors for the formation of nanoparticles of elemental metals or intermetallic compounds, have been systematized and discussed. It has been noted that each of these metal clusters in principle is able to exist in very diverse structural isomers, differing significantly among themselves in terms of the total energy and spin multiplicity of the ground state, the number of which is determined by both the specific values of $n$ and $m$, and the nature of $d$-elements in their compositions. The presence of very complex dynamics with respect to the changes of the individual thermodynamic characteristics of the metal clusters under consideration as well as the thermodynamic parameters of the reactions of their formation, depending on the nature of the $d$-element, were also ascertained. In the main, the given review is devoted to the authors' works published over the last 10 years. Bibliography - 96 references.
\end{abstract}

Keywords: metal cluster; aluminum; $d$-element; molecular structure; thermodynamic parameters; DFT method

\section{Introduction}

As is known, micro- and nanoparticles of elemental metals and their compositions, and primarily from among $p$ - and $d$-elements, are now very important in modern chemistry and chemical technology. On the one hand, they are a kind of "precursor" for the production of micro- and nanoparticles of metal oxides, metal sulfides, and metal chalcogenides (which, in turn, appear to be very convenient starting materials for producing, for example, ceramic materials, catalytic and sorption systems). On the other hand, they themselves have a number of specific (and very useful) properties from an anthropogenic point of view. There is great interest in this type of nanoparticle, i.e., those that contain two or more different chemical elements in their structural units, because in this case, from purely theoretical considerations, it is very likely that they will have a number of new properties that are not observed in nanoparticles containing atoms of only one chemical element. These nanoparticles are composed of heteronuclear metal clusters with chemical metal-metal bonds formed by identical as well as different atoms. In view of the circumstance just noted, it seems to be an urgent task related to both confirming the very principal possibility of the existence of nanoparticles consisting of various metal elements and having a specific chemical composition, and if confirmed, by revealing all possible structural forms and configurations for them with using modern quantum chemical calculations. 
To date, a very significant number of studies have been devoted to heteropolynuclear metal clusters with a diverse number and assortment of metal atoms in structural units-their number is measured in many hundreds, and all of them in this review paper cannot be simply cited. Most of them were devoted to heteropolynuclear metal clusters containing atoms of various $3 d, 4 d$, and $5 d$ elements. In particular, are related the publications [1-50]. Some such metal clusters have been applied in various fields of science and technology (see, f.e., [1,3,20,36,37]). In the works cited above [1-50], the objects of study were the so-called $(d d)$ heterobimetallic metal clusters, which included atoms of two different $d$-elements, in particular, ( $\mathrm{Au}, \mathrm{Fe})$ [9], ( $\mathrm{Pd}, \mathrm{Ag})[12,21,43],(\mathrm{Au}, \mathrm{Ag})[26],(\mathrm{Au}, \mathrm{Pd})[33],(\mathrm{Cu}$, $\mathrm{Fe})[38]$ and $(\mathrm{Pt}, \mathrm{Cu})$ [39]. However, of no less interest are the $(p d)$ heterobimetallic metal clusters that include atoms of different categories of metals, namely, $p$ - and $d$-elements, since theoretically it can be expected that they will demonstrate such new properties that are not inherent to metal clusters containing metal atoms of only one category. These metal clusters, however, were considered in a much smaller number of works, in particular, in [51-63].

Heterometallic metal clusters containing the atoms of those metals that are important in various fields of science and technology, namely aluminum and $3 d$ elements $(\mathrm{M})$, are very interesting objects from both a purely academic and practical points of view in this field. Some of them, in particular, $\mathrm{Sc}_{\mathrm{n}} \mathrm{Al}, \mathrm{Y}_{\mathrm{n}} \mathrm{Al}$, and $\mathrm{Al}_{\mathrm{n}} \mathrm{Ti}$, were considered in [58-63]. Such metal clusters, however, contain only two types of chemical bonds, namely either $\mathrm{M}-\mathrm{M}$ and $\mathrm{Al}-\mathrm{M}$, or $\mathrm{Al}-\mathrm{M}$ and $\mathrm{Al}-\mathrm{Al}$. More interesting for consideration are those $(p d)$ metal clusters that contain all three possible chemical bonds here, namely $\mathrm{M}-\mathrm{M}, \mathrm{Al}-\mathrm{M}$, and $\mathrm{Al}-\mathrm{Al}$. The simplest of them are tetranuclear metal clusters, where in principle, two different types of geometric bodies are possible, at the vertices of which there are $\mathrm{M}$ and $\mathrm{Al}$ atoms, namely a quadrangle and a tetrahedron, and structural variations are already quite diverse. However, much greater possibilities in terms of the diversity of molecular structures open up starting from five-atom clusters. At the present time, there is already a number of publications that have examined the structural features of this category of $(p d)$ metal clusters consisting of four, five, and six atoms, and the quantum-chemical calculations of these metal clusters were carried out using the density functional method (DFT) combining the standard extended split-valence QZVP basis $[64,65]$ and the OPBE functional $[66,67]$. To build quantum chemical models of the molecular structures of the metal clusters under examination, GAUSSIAN09 software was used [68]. Moreover, the accordance of the found stationary points to the energy minima was confirmed by calculation of the second derivatives with respect to the atomic coordinates. Further, all equilibrium structures corresponding to the minima at the potential energy surface revealed only real positive frequency values. Parameters of the molecular structures for spin multiplicities $\left(M_{S}\right)$ more than 1 , were determined using the so-called unrestricted method (UOPBE), for $M_{S}=1$, using so-called restricted method (ROPBE). Along with this, the unrestricted method in conjunction with the GUESS = Mix option was used for the cases when $M_{S}$ was equal to 1 . The data obtained as a result of such a procedure, were similar to those obtained using ROPBE method. The data of works [69-72] give us reason to assert that the given method allows to obtain the most accurate estimation of ratio between energies of the high-spin state and low-spin state and, at the same time, rather reliably predicts the key geometric parameters of molecular structures for various compounds of $3 p$ - and $3 d$-elements. That is why the DFT OPBE/QZVP method was used by authors of the given review article in the calculation of molecular structures in all their works [73-96], where such ( $p d$ )metal clusters were considered. The given review paper will be devoted to the systematization and discussion of the main results of those calculations that are presented, namely in these publications.

\section{Tetranuclear (A1M) Metal Clusters}

Tetranuclear metal clusters containing aluminum atoms and $d$-metal atoms $\mathrm{M}$ can be divided into three categories depending on the number of both these atoms in the molecule, namely $\mathrm{AlM}_{3}$, $\mathrm{Al}_{2} \mathrm{M}_{2}$, and $\mathrm{Al}_{3} \mathrm{M}$. Currently, information on metal clusters with such stoichiometric compositions is available only for one of the $d$-elements, namely for $\mathrm{M}=\mathrm{Fe}$. Such metal clusters were considered 
by us in the works [73-80]. In the earliest of them [73], a metal cluster of $\mathrm{AlFe}_{3}$ composition was described, for which the total number of theoretically possible isomers (4) was revealed in this work, and data on the coordinates of the iron and aluminum atoms included in its composition were presented. Similar information on the total number of isomers of this metal cluster is reported in publications [74,75]. However, a more detailed consideration of this metal cluster and its analogue with the inverse relationship between the numbers of $\mathrm{Al}$ and $\mathrm{Fe}$ atoms, namely $\mathrm{Al}_{3} \mathrm{Fe}$, is carried out in [76,77], revealing the presence of 10 isomers of $\mathrm{AlFe}_{3}$ and seven isomers of $\mathrm{Al}_{3} \mathrm{Fe}$. Information on their relative stability is presented in Table 1 . In the same works, the parameters of the molecular structures of all these isomers were presented. According to them, in eight isomers of $\mathrm{AlFe}_{3}$, aluminum and iron atoms are located at the vertices of a distorted tetrahedron, distorted to one degree or another. In the other two, all four atoms are located in the same plane. It is characteristic that, in any of these ten isomers, all three theoretically possible Al-Fe chemical bonds are present, while three Fe-Fe bonds are present in only two isomers, and in most of them (in seven), only one such bond is realized. In this connection, we should note that, among these ten isomers, there is one in which there are no bonds between the atoms of the above $d$-element. At the same time, curiously, the most stable in energy terms (i.e., having the lowest total energy among all other isomers) is one of those seven isomers in which there is only one Fe-Fe bond [76,77]. According to the data presented in these publications, the ground state of this isomer is the spin quartet. The isomers closest to it in terms of total energy have a doublet and quartet ground state and are almost identical energies, which are only slightly larger than the total energy of the most stable isomer (by 11.2 and $11.3 \mathrm{~kJ} / \mathrm{mol}$, respectively). Isomers of the $\mathrm{Al}_{3} \mathrm{Fe}$ metal cluster, despite the closeness of their formal stoichiometric compositions to $\mathrm{AlFe}_{3}$ isomers, nevertheless are quite significantly different from $\mathrm{AlFe}_{3}$ isomers, not only in their total number, but also in appearance $[76,77]$. In six of seven isomers of $\mathrm{Al}_{3} \mathrm{Fe}$, there are all three theoretically admissible $\mathrm{Al}-\mathrm{Fe}$ chemical bonds, and only one has such a bond. As in the $\mathrm{AlFe}_{3}$ metal cluster, there are distorted tetrahedral and planar structures ( 4 and 3, respectively). However, here, unlike $\mathrm{AlFe}_{3}$, the most energy stable isomer contains a complete set of metal - metal bonds (three Al-Fe bonds and three $\mathrm{Fe}-\mathrm{Fe}$ bonds). Molecular structures of both these isomers are shown in Figure 1. The Al-Fe chemical bond lengths in $\mathrm{AlFe}_{3}$ isomers are generally somewhat longer than those in $\mathrm{Al}_{3} \mathrm{Fe}$, which may be connected with the absence of a complete set of $\mathrm{Fe}-\mathrm{Fe}$ chemical bonds in most $\mathrm{AlFe}_{3}$ isomers $[76,77]$.

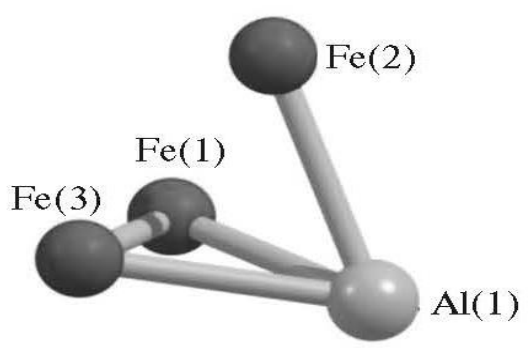

(a)

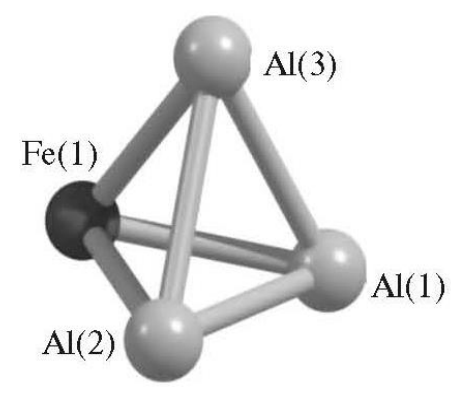

(b)

Figure 1. The images of molecular structures of most stable $\mathrm{AlFe}_{3}(\mathbf{a})$ and $\mathrm{Al}_{3} \mathrm{Fe}(\mathbf{b})$ isomers [76].

Another theoretically possible (AlFe) tetranuclear metal cluster, namely $\mathrm{Al}_{2} \mathrm{Fe}_{2}$, was considered in [78-80]. Unlike the $\mathrm{AlFe}_{3}$ and $\mathrm{Al}_{3} \mathrm{Fe}$ metal clusters, it contains all three of the above types of chemical bonds ( $\mathrm{M}-\mathrm{M}, \mathrm{Al}-\mathrm{M}$ and $\mathrm{Al}-\mathrm{Al})$, and therefore more isomers can be expected here. Indeed, according to the data of [78-80], it can exist in 12 different isomers (Table 1), the most energetically favorable of which has the structure of a distorted tetrahedron with the maximum theoretically possible set of chemical bonds Al-Fe and Fe-Fe (three each of these types of bonds) (Figure 2). Outwardly, this isomer resembles the one shown in Figure 1b, but in it all four Al-Fe bonds have the same length (249.5 pm each), while in $\mathrm{Al}_{3} \mathrm{Fe}$ all these bonds are different and generally shorter $(234.6,236.7$, and $250.6 \mathrm{pm}$ ) $[79,80]$. For the majority of other isomers of $\mathrm{Al}_{2} \mathrm{Fe}_{2}$ (seven out of 12), as well as for tetranuclear 
metal clusters already considered in this section (AlFe), the geometry of the distorted tetrahedron is more typical, although flat or almost coplanar structures also occupy a prominent place [78-80]. Isomers of $\mathrm{Al}_{2} \mathrm{Fe}_{2}$ with this form, however, have total energy values of more than $100 \mathrm{~kJ} / \mathrm{mol}$ higher than the total energy of the most low-energy isomer. Further, the total amount of chemical bonds $\mathrm{Al}-\mathrm{Al}, \mathrm{Al}-\mathrm{Fe}$, and $\mathrm{Fe}-\mathrm{Fe}$ in these isomers ranges from 4 to 6 . The first of these bonds is absent only in one isomer, and the third, in two isomers of the metal cluster under examination. It should be noted in this connection that the lengths of the $\mathrm{M}-\mathrm{M}, \mathrm{Al}-\mathrm{M}$, and $\mathrm{Al}-\mathrm{Al}$ bonds in various isomers of these metal clusters are in such ranges that, given the atomic radii of $\mathrm{Al}(143 \mathrm{pm})$ and $\mathrm{Fe}(126 \mathrm{pm})$, appear quite natural and predictable. In particular, in $\mathrm{Al}_{3} \mathrm{Fe}$ isomers, $\mathrm{Al}-\mathrm{Al}$ bond lengths are in the range of 257-277 pm, Al-Fe bond lengths are in the range of 235-255 pm. In $\mathrm{AlFe}_{3}$ isomers, Fe-Fe bond lengths are in the range of 207-219 pm, Al-Fe bond lengths are in the range of 238-276 pm. At the same time, most of the valence (bond) angles of these same bonds, as well as the torsion (dihedral) angles, have values substantially less than $90^{\circ}$. The more detailed information on the structural parameters of the most energetically stable of the above metal clusters is presented in Table 2.

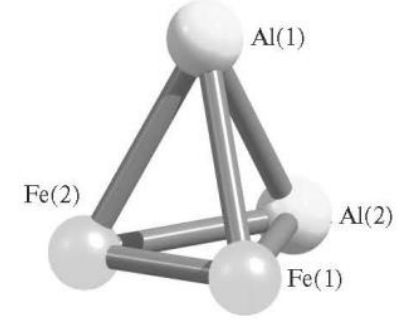

Figure 2. The image of molecular structure of most stable $\mathrm{Al}_{2} \mathrm{Fe}_{2}$ isomer [79].

Table 1. Relative energies and spin multiplicities of the ground states of various isomers of metal clusters $\mathrm{Al}_{3} \mathrm{Fe}, \mathrm{AlFe}_{3}$ and $\mathrm{Al}_{2} \mathrm{Fe}_{2}$. Roman numerals in the table are the designations of these metal clusters presented in the original works.

\begin{tabular}{|c|c|c|c|}
\hline $\begin{array}{c}\text { Structure } \\
\text { Designation }\end{array}$ & $\begin{array}{l}\text { Spin Multiplicity of } \\
\text { the Ground State }\end{array}$ & Relative Energy, kJ/mol & Ref. \\
\hline \multicolumn{4}{|c|}{$\mathrm{Al}_{3} \mathrm{Fe}$ Metal Cluster } \\
\hline $\mathrm{Al}_{3} \mathrm{Fe}(\mathrm{I})$ & 2 & 0.0 & \multirow{7}{*}[79,80]{} \\
\hline $\mathrm{Al}_{3} \mathrm{Fe}(\mathrm{VII})$ & 2 & 175.1 & \\
\hline $\mathrm{Al}_{3} \mathrm{Fe}(\mathrm{II})$ & 4 & 32.7 & \\
\hline $\mathrm{Al}_{3} \mathrm{Fe}(\mathrm{IV})$ & 4 & 153.3 & \\
\hline $\mathrm{Al}_{3} \mathrm{Fe}(\mathrm{III})$ & 6 & 83.4 & \\
\hline $\mathrm{Al}_{3} \mathrm{Fe}(\mathrm{VI})$ & 6 & 84.8 & \\
\hline $\mathrm{Al}_{3} \mathrm{Fe}(\mathrm{V})$ & 6 & 193.1 & \\
\hline \multicolumn{4}{|c|}{$\mathrm{AlFe}_{3}$ Metal Cluster } \\
\hline $\mathrm{AlFe}_{3}(\mathrm{II})$ & 2 & 11.2 & \multirow{10}{*}[79,80]{} \\
\hline $\mathrm{AlFe}_{3}(\mathrm{I})$ & 2 & 104.0 & \\
\hline $\mathrm{AlFe}_{3}$ (VII) & 2 & 122.8 & \\
\hline $\mathrm{AlFe}_{3}$ (VIII) & 2 & 198.7 & \\
\hline $\mathrm{AlFe}_{3}(\mathrm{~V})$ & 4 & 0.0 & \\
\hline $\mathrm{AlFe}_{3}$ (III) & 4 & 11.3 & \\
\hline $\mathrm{AlFe}_{3}$ (IX) & 4 & 150.2 & \\
\hline $\mathrm{AlFe}_{3}(\mathrm{VI})$ & 6 & 17.4 & \\
\hline $\mathrm{AlFe}_{3}$ (IV) & 6 & 41.7 & \\
\hline $\mathrm{AlFe}_{3}(\mathrm{X})$ & 6 & 52.6 & \\
\hline \multicolumn{4}{|c|}{$\mathrm{Al}_{2} \mathrm{Fe}_{2}$ Metal Cluster } \\
\hline $\mathrm{Al}_{2} \mathrm{Fe}_{2}(\mathrm{XII})$ & 1 & 45.1 & \\
\hline $\mathrm{Al}_{2} \mathrm{Fe}_{2}(\mathrm{VII})$ & 1 & 46.7 & [78-80] \\
\hline $\mathrm{Al}_{2} \mathrm{Fe}_{2}(\mathrm{IX})$ & 1 & 150.3 & \\
\hline
\end{tabular}


Table 1. Cont.

\begin{tabular}{cccc}
\hline $\begin{array}{c}\text { Structure } \\
\text { Designation }\end{array}$ & $\begin{array}{c}\text { Spin Multiplicity of } \\
\text { the Ground State }\end{array}$ & Relative Energy, kJ/mol & Ref. \\
\cline { 1 - 3 } $\mathrm{Al}_{2} \mathrm{Fe}_{2}(\mathrm{X})$ & 1 & 209.8 & \\
$\mathrm{Al}_{2} \mathrm{Fe}_{2}(\mathrm{III})$ & 1 & 352.5 & \\
\hline $\mathrm{Al}_{2} \mathrm{Fe}_{2}$ (VI) & 3 & 66.5 & \\
$\mathrm{Al}_{2} \mathrm{Fe}_{2}$ (VIII) & 3 & 68.4 & \\
$\mathrm{Al}_{2} \mathrm{Fe}_{2}(\mathrm{IV})$ & 3 & 137.9 & \\
$\mathrm{Al}_{2} \mathrm{Fe}_{2}(\mathrm{XI})$ & 3 & 143.6 & \\
$\mathrm{Al}_{2} \mathrm{Fe}_{2}$ (II) & 3 & 254.5 & \\
\hline $\mathrm{Al}_{2} \mathrm{Fe}_{2}$ (V) & 5 & 0.0 & \\
$\mathrm{Al}_{2} \mathrm{Fe}_{2}$ (I) & 5 & 152.7 \\
\hline
\end{tabular}

Table 2. Key structural parameters of most stable $\mathrm{Al}_{3} \mathrm{Fe}, \mathrm{Al}_{2} \mathrm{Fe}_{2}$ and $\mathrm{AlFe}$ metal clusters * [76-80].

\begin{tabular}{|c|c|c|c|c|c|}
\hline \multicolumn{2}{|c|}{$\mathrm{Al}_{3} \mathrm{Fe}$ Metal Cluster } & \multicolumn{2}{|c|}{$\mathrm{Al}_{2} \mathrm{Fe}_{2}$ Metal Cluster } & \multicolumn{2}{|c|}{$\mathrm{AlFe}_{3}$ Metal Cluster } \\
\hline \multicolumn{2}{|c|}{ Metal-Metal Bond Lengths, pm } & \multicolumn{2}{|c|}{ Metal-Metal Bond Lengths, pm } & \multicolumn{2}{|c|}{ Metal-Metal Bond Lengths, pm } \\
\hline $\mathrm{Al1Al2}$ & 263.4 & $\mathrm{Al} 1 \mathrm{Al} 2$ & 260.8 & Al1Fe1 & 249.1 \\
\hline $\mathrm{Al1Al3}$ & 263.3 & Al1Fe1 & 249.5 & Al1Fe2 & 249.1 \\
\hline $\mathrm{Al} 2 \mathrm{Al} 3$ & 274.3 & $\mathrm{Al} F \mathrm{Fe} 2$ & 249.4 & Al1Fe3 & 255.5 \\
\hline Al1Fe1 & 245.7 & $\mathrm{Al} 2 \mathrm{Fe} 1$ & 249.5 & Fe1Fe2 & 208.6 \\
\hline $\mathrm{Al} 2 \mathrm{Fe} 1$ & 235.0 & $\mathrm{Al} 2 \mathrm{Fe} 2$ & 249.5 & Fe1Fe3 & 248.7 \\
\hline $\mathrm{Al} 3 \mathrm{Fe} 1$ & 235.1 & Fe1Fe2 & 199.2 & $\mathrm{Fe} 2 \mathrm{Fe} 3$ & 248.7 \\
\hline \multicolumn{2}{|c|}{ Bond Angles, deg } & \multicolumn{2}{|c|}{ Bond Angles, deg } & \multicolumn{2}{|c|}{ Bond Angles, deg } \\
\hline Al1Fe1Al2 & 66.4 & Fe1Al1Fe2 & 47.1 & Fe1Al1Fe2 & 49.5 \\
\hline Fe1Al1Al2 & 54.9 & $\mathrm{Fe} 1 \mathrm{Al} 2 \mathrm{Fe} 2$ & 47.1 & Al1Fe1Fe2 & 65.3 \\
\hline $\mathrm{Al} 1 \mathrm{Al} 2 \mathrm{Fe} 1$ & 58.7 & Fe1Al1Al2 & 58.5 & Fe1Fe2Al1 & 65.2 \\
\hline Al1Fe1Al3 & 66.4 & Fe1Al2Al1 & 58.5 & Fe1Al1Fe3 & 59.0 \\
\hline $\mathrm{Al} 2 \mathrm{Fe} 1 \mathrm{Al} 3$ & 71.4 & Fe2Al1Al2 & 58.5 & $\mathrm{Fe} 2 \mathrm{Al} 1 \mathrm{Fe} 3$ & 59.0 \\
\hline $\mathrm{Al} 1 \mathrm{Al} 2 \mathrm{Al} 3$ & 58.6 & Fe2Al2Al1 & 58.5 & $\mathrm{Fe} 1 \mathrm{Fe} 2 \mathrm{Fe} 3$ & 65.2 \\
\hline $\mathrm{Al} 2 \mathrm{Al} 3 \mathrm{Al} 1$ & 58.6 & Al1Fe1Al2 & 63.0 & $\mathrm{Fe} 2 \mathrm{Fe} 3 \mathrm{Fe} 1$ & 49.6 \\
\hline $\mathrm{Al} 3 \mathrm{Al} 1 \mathrm{Al} 2$ & 62.8 & Al1Fe2Al2 & 63.1 & $\mathrm{Fe} 3 \mathrm{Fe} 1 \mathrm{Fe} 2$ & 65.2 \\
\hline
\end{tabular}

* The interatomic distances and angles within which at least one of the metal-metal bonds ( $\mathrm{Al}-\mathrm{Al}, \mathrm{Al}-\mathrm{M}$, or $\mathrm{M}-\mathrm{M})$ is absent, are shown in this table in italics.

The images of molecular structures of all these tetranuclear metal clusters are presented in Supplementary Materials (Figures S1-S3).

In $[79,80]$, a quantum-chemical calculation of the parameters of molecular structures of (heterotri)tetranuclear metal cluster having the composition $\mathrm{Al}_{2} \mathrm{FeCo}$, was also carried out, for which it was found that only three isomers could be found that look very similar to each other (Figure 3).

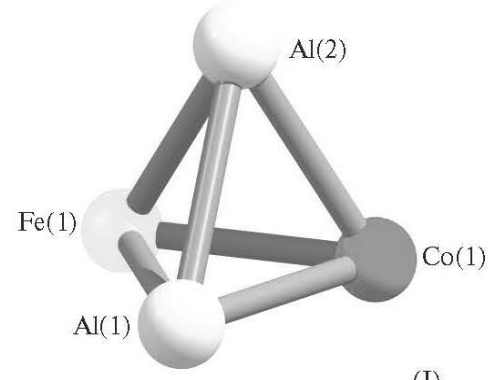

(I)

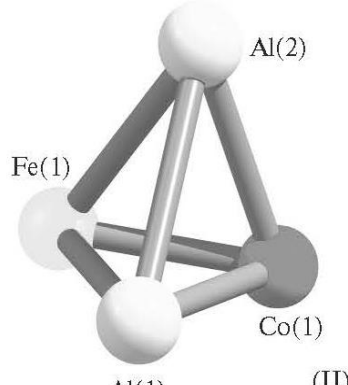

$\mathrm{Al}(1)$

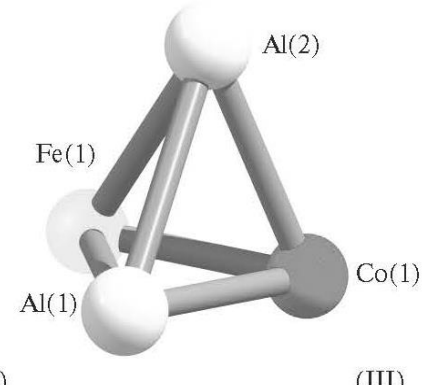

(III)

Figure 3. Molecular structures of three $\mathrm{Al}_{2} \mathrm{FeCo}$ isomers: (I) —with most high energy, (III) —with most low energy and (II) — with intermediate energy between (I) and (III) [79]. 
These isomers, however, are very different from each other in total energy values as well as the spin multiplicity of the ground state. There is no doubt that (heterobi)tetranuclear metal clusters containing aluminum atoms and atoms of other $d$-elements are also possible, but no information has appeared in the literature on this subject yet.

\section{Pentanuclear (AIM) Metal Clusters}

The given type of metal clusters has been analyzed in much more detail than tetrabinuclear ones, and is currently known for all $3 d$ elements (except for Sc), as well as for two $4 d$ elements (Mo and $\mathrm{Ag}$ ). It should be noted, however, that all of these metal clusters are of the same type and have the same stoichiometric composition of $\mathrm{Al}_{2} \mathrm{M}_{3}$. Meanwhile, pentabinuclear metal clusters with other theoretically possible sets of aluminum atoms and $d$-element atoms in the molecule (and namely, $\mathrm{Al}_{4} \mathrm{M}, \mathrm{Al}_{3} \mathrm{M}_{2}$ and $\mathrm{AlM}_{4}$ ) have not yet been considered. The specifics of molecular structures and thermodynamic characteristics of such metal clusters having the composition indicated above, where $\mathrm{M}$ is a $3 d$ element, are discussed in [74,75,81-91]. We should note immediately that, according to the calculation data by the DFT method, for each of these $\mathrm{M}$, there is an individual set of isomers, both in assortment and in their total number $(N)$, which varies over a very wide range-from 7 (in the case of $\mathrm{Al}_{2} \mathrm{Ni}_{3}$ ) to 25 (in the case of $\mathrm{Al}_{2} \mathrm{Mn}_{3}$ ) (Table 3). The relative total energies of these isomers also vary over a very wide range (Table 4 ). The most energetically advantageous among these isomers for the above $\mathrm{M}$ are shown in Figure 4. The molecular structure parameters of these isomers are given in Table 5. A complete assortment of molecular structures of all metal clusters considered by us can be found in the publications [74,75,81-91] cited above, and in the Supplemental Materials.

Table 3. Total number of $\mathrm{Al}_{2} \mathrm{M}_{3}(N)$ metal cluster isomers for various $\mathrm{M}$ of $3 d$-elements.

\begin{tabular}{cccccccccc}
\hline $\mathbf{M}$ & $\mathbf{T i}$ & $\mathbf{V}$ & $\mathbf{C r}$ & $\mathbf{M n}$ & $\mathbf{F e}$ & $\mathbf{C o}$ & $\mathbf{N i}$ & $\mathbf{C u}$ & $\mathbf{Z n}$ \\
\hline$N$ & 14 & 11 & 20 & 25 & 8 & 9 & 7 & 8 & 14 \\
Ref. & {$[81,83]$} & {$[82,83]$} & {$[84,85]$} & {$[86]$} & {$[87-89]$} & {$[87,88]$} & {$[87,88]$} & {$[89-91]$} & {$[86]$} \\
\hline
\end{tabular}

According to data presented in [81,83], of the 14 identified isomers of the $\mathrm{Al}_{2} \mathrm{Ti}_{3}$ metal cluster, only $\mathrm{Al}-\mathrm{Al}$ valence bonds are realized in only seven of them, namely, $\mathrm{Al}_{2} \mathrm{Ti}_{3}$ (I), $\mathrm{Al}_{2} \mathrm{Ti}_{3}(\mathrm{II}), \mathrm{Al}_{2} \mathrm{Ti}_{3}$ (IV), $\mathrm{Al}_{2} \mathrm{Ti}_{3}(\mathrm{~V}), \mathrm{Al}_{2} \mathrm{Ti}_{3}(\mathrm{VII}), \mathrm{Al}_{2} \mathrm{Ti}_{3}(\mathrm{VIII})$, and $\mathrm{Al}_{2} \mathrm{Ti}_{3}(\mathrm{X})$, the direct valence bonds $\mathrm{Al}-\mathrm{Ti}$ and $\mathrm{Ti}-\mathrm{Ti}$, at least in the singular, each occur in all these metal clusters. The most favorable in terms of energy is the $\mathrm{Al}_{2} \mathrm{Ti}_{3}$ (XI) isomer with spin multiplicity $M_{S}=5$ and the geometry of the trigonal bipyramid (Figure 4a), in the "equatorial plane" of which there are three titanium atoms, the aluminum atoms are located at its vertices. The $\mathrm{Al}_{2} \mathrm{Ti}_{3}$ (XII) isomer with $M_{S}=3$ following the increase in total energy, has a similar structure. Four of these isomers, namely $\mathrm{Al}_{2} \mathrm{Ti}_{3}(\mathrm{IV}), \mathrm{Al}_{2} \mathrm{Ti}_{3}(\mathrm{~V}), \mathrm{Al}_{2} \mathrm{Ti}_{3}(\mathrm{IX})$, and $\mathrm{Al}_{2} \mathrm{Ti}_{3}$ (XI), have a spin multiplicity 5, the same, namely, $\mathrm{Al}_{2} \mathrm{Ti}_{3}(\mathrm{I}), \mathrm{Al}_{2} \mathrm{Ti}_{3}(\mathrm{VI}), \mathrm{Al}_{2} \mathrm{Ti}_{3}(\mathrm{X}), \mathrm{Al}_{2} \mathrm{Ti}_{3}$ (XII), spin multiplicity 3. In the remaining six, the spin singlet turns out to be the ground state. As it may be seen, the spin state with $M_{S}=1$ for the metal cluster under consideration is predominant, although in fairness, it should be noted that the closest in energy to the $\mathrm{Al}_{2} \mathrm{Ti}_{3}(\mathrm{XI})$ isomer are the $\mathrm{Al}_{2} \mathrm{Ti}_{3}$ (XII) and $\mathrm{Al}_{2} \mathrm{Ti}_{3}(\mathrm{~V})$ isomers with relative energies of 12.6 and $19.7 \mathrm{~kJ} / \mathrm{mol}$, respectively, exceeding the energy of $\mathrm{Al}_{2} \mathrm{Ti}_{3}(\mathrm{XI})$, having $M_{S}=3$ and 5, respectively (Table 4).

In $[82,83]$, a quantum chemical calculation of the $\mathrm{Al}_{2} \mathrm{~V}_{3}$ metal cluster was carried out. Information on the relative energy of its isomers is presented in Table 4 . As can be seen from Table 4 , in six out of 11 isomers of this metal cluster, namely in $\mathrm{Al}_{2} \mathrm{~V}_{3}(\mathrm{I})-\mathrm{Al}_{2} \mathrm{~V}_{3}$ (VI), there is a direct $\mathrm{Al}-\mathrm{Al}$ valence bond, while in the other five, it is absent and only V-V and V-Al bonds take place in them. Moreover, that is noteworthy, in two structures, namely $\mathrm{Al}_{2} \mathrm{~V}_{3}$ (VIII) and $\mathrm{Al}_{2} \mathrm{~V}_{3}$ (IX), only chemical bonds between atoms of different chemical elements (i.e., $\mathrm{V}-\mathrm{Al}$ ) take place, while between the same atoms there are none (which, by the way, in none of the $\mathrm{Al}_{2} \mathrm{Ti}_{3}$ metal clusters described above is observed). As in the case of the $\mathrm{Al}_{2} \mathrm{Ti}_{3}$ metal cluster, its most stable isomer, namely $\mathrm{Al}_{2} \mathrm{~V}_{3}(\mathrm{~V})$, has not the highest spin multiplicity (6), but a lower (though not the lowest) (4). At the same time, that is characteristic, structures with the 
highest spin multiplicity 6 as a whole have noticeably higher values of the total energies than structures with multiplicities 2 and 4 . In addition, the $\mathrm{Al}_{2} \mathrm{~V}_{3}$ (II) structure closest in energy to $\mathrm{Al}_{2} \mathrm{~V}_{3}$ (V) possesses the same spin multiplicity, and its molecular structure resembles the structure of $\mathrm{Al}_{2} \mathrm{~V}_{3}(\mathrm{~V})$, at least in general terms. At the same time, the following three structures with increasing energy, namely, $\mathrm{Al}_{2} \mathrm{~V}_{3}$ (III), $\mathrm{Al}_{2} \mathrm{~V}_{3}(\mathrm{I})$, and $\mathrm{Al}_{2} \mathrm{~V}_{3}$ (IV), have different values of spin multiplicity, namely, 6, 2, and 2, respectively. The most unstable is the isomer $\mathrm{Al}_{2} \mathrm{~V}_{3}$ (IX), the total energy of which is not only much higher (almost $150 \mathrm{~kJ} / \mathrm{mol}$ ) compared with that for $\mathrm{Al}_{2} \mathrm{~V}_{3}(\mathrm{~V})$, but also all other isomers of the metal cluster under consideration, which is noteworthy, as it has the highest spin multiplicity $(6)[82,83]$.

For the $\mathrm{Al}_{2} \mathrm{Cr}_{3}$ metal cluster, 20 different isomers were found (Table 3). In thirteen of them, namely, in $\mathrm{Al}_{2} \mathrm{Cr}_{3}(\mathrm{I}), \mathrm{Al}_{2} \mathrm{Cr}_{3}(\mathrm{III})-\mathrm{Al}_{2} \mathrm{Cr}_{3}(\mathrm{XII}), \mathrm{Al}_{2} \mathrm{Cr}_{3}$ (XVI) and $\mathrm{Al}_{2} \mathrm{Cr}_{3}$ (XVII), there is a direct valence $\mathrm{Al}-\mathrm{Al}$ bond, while in the other seven it is absent in only $\mathrm{Cr}-\mathrm{Cr}$ and $\mathrm{Cr}-\mathrm{Al}$ bonds are realized in them $[84,85]$. On the other hand, $\mathrm{Cr}-\mathrm{Cr}$ bonds are present in only six isomers: $\mathrm{Al}_{2} \mathrm{Cr}_{3}(\mathrm{I}), \mathrm{Al}_{2} \mathrm{Cr}_{3}(\mathrm{~V}), \mathrm{Al}_{2} \mathrm{Cr}_{3}(\mathrm{VI})$, $\mathrm{Al}_{2} \mathrm{Cr}_{3}(\mathrm{X}), \mathrm{Al}_{2} \mathrm{Cr}_{3}$ (XIII) and $\mathrm{Al}_{2} \mathrm{Cr}_{3}$ (XIX). Further, with the last three isomers, chromium atoms are paired together. In three structures, namely $\mathrm{Al}_{2} \mathrm{Cr}_{3}(\mathrm{II}), \mathrm{Al}_{2} \mathrm{Cr}_{3}(\mathrm{XIV})$, and $\mathrm{Al}_{2} \mathrm{Cr}_{3}(\mathrm{XV})$, only chemical bonds between atoms of different chemical elements (i.e., $\mathrm{Cr}-\mathrm{Al}$ ) take place, but there are no bonds between identical atoms (i.e., $\mathrm{Al}-\mathrm{Al}$ and $\mathrm{Cr}-\mathrm{Cr}$ ). Information on the relative energy of these isomers is given in Table 4. As can be seen from Table 4, the most stable isomer of this metal cluster, $\mathrm{Al}_{2} \mathrm{Cr}_{3}$ (III), also does not have the highest spin multiplicity (7), but is somewhat lower (5). Incidentally, structures with a higher spin multiplicity 7 in general also have larger total energies than structures with a multiplicity of 5 (although smaller than structures with a multiplicity of 1 and 3) [84,85]. It is interesting that this isomer is the only one among the most stable isomers of $\mathrm{Al}_{2} \mathrm{M}_{3}$ in which there are no $\mathrm{M}-\mathrm{M}$ bonds (Figure 4c), because in all the most stable isomers of the given composition of metal clusters formed by $\mathrm{M}$ atoms of the other $3 d$ elements, at least one such a bond occurs (see Figure $4 \mathrm{a}, \mathrm{b}, \mathrm{d}-\mathrm{i}$ ).

The $\mathrm{Al}_{2} \mathrm{Mn}_{3}$ metal cluster is able to exist in 25 different isomers [86]. This amount is the largest among all $\mathrm{Al}_{2} \mathrm{M}_{3}$ metal clusters formed by $3 d$ element atoms (Table 4 ). Further, only 10 of the structures, namely $\mathrm{Al}_{2} \mathrm{Mn}_{3}$ (I)- $\mathrm{Al}_{2} \mathrm{Mn}_{3}$ (VII), $\mathrm{Al}_{2} \mathrm{Mn}_{3}$ (IX), $\mathrm{Al}_{2} \mathrm{Mn}_{3}$ (XII) and $\mathrm{Al}_{2} \mathrm{Mn}_{3}$ (XIV) contain a covalent $\mathrm{Al}-\mathrm{Al}$ bond, whereas the other 15 ones, $\mathrm{Al}_{2} \mathrm{Mn}_{3}$ structures contain only the $\mathrm{Mn}-\mathrm{Mn}$ and $\mathrm{Mn}-\mathrm{Al}$ bonds, and the $\mathrm{Al}-\mathrm{Al}$ one is absent. In most of these isomers (16 of 25) there are $6 \mathrm{Mn}$ - $\mathrm{Al}$ bonds, in $\operatorname{six}\left[\mathrm{Al}_{2} \mathrm{Mn}_{3}\right.$ (I) $\left.-\mathrm{Al}_{2} \mathrm{Mn}_{3}(\mathrm{~V}), \mathrm{Al}_{2} \mathrm{Mn}_{3}(\mathrm{XIV})\right]-5$, and in three $\left[\mathrm{Al}_{2} \mathrm{Mn}_{3}\right.$ (IX), $\mathrm{Al}_{2} \mathrm{Mn}_{3}$ (X) and $\mathrm{Al}_{2} \mathrm{Mn}_{3}$ (XIII)] by 4. Finally, in most isomers (15 of 25) there is a complete set of Mn-Mn links (by 3). In seven isomers $\left[\mathrm{Al}_{2} \mathrm{Mn}_{3}(\mathrm{VI})-\mathrm{Al}_{2} \mathrm{Mn}_{3}(\mathrm{VIII}), \mathrm{Al}_{2} \mathrm{Mn}_{3}(\mathrm{XI})-\mathrm{Al}_{2} \mathrm{Mn}_{3}(\mathrm{XIII}), \mathrm{Al}_{2} \mathrm{Mn}_{3}(\mathrm{XXV})\right]$, there are two such bonds and in three isomers $\left[\mathrm{Al}_{2} \mathrm{Mn}_{3}\right.$ (I), $\mathrm{Al}_{2} \mathrm{Mn}_{3}$ (II) and $\mathrm{Al}_{2} \mathrm{Mn}_{3}$ (XXIV)]-by one [86]. The most energetically favorable $\mathrm{Al}_{2} \mathrm{Mn}_{3}$ (VI) isomer has the spin multiplicity of ground state $M_{S}=6$, and contains maximal number of $\mathrm{Al}-\mathrm{Al}$ and $\mathrm{Al}-\mathrm{Mn}$ bonds [although number of $\mathrm{Mn}-\mathrm{Mn}$ in it is lesser than maximal possible number of such bonds (3)] (Figure 4d). The isomer $\mathrm{Al}_{2} \mathrm{Mn}_{3}(\mathrm{XX})$ has relative total energy only by $1.4 \mathrm{~kJ} / \mathrm{mol}$ higher than total energy of $\mathrm{Al}_{2} \mathrm{Mn}_{3}(\mathrm{VI})$ isomer and the same multiplicity (6). Its geometric configuration is similar to $\mathrm{Al}_{2} \mathrm{Mn}_{3}$ (VI), however, unlike $\mathrm{Al}_{2} \mathrm{Mn}_{3}$ (VI), $\mathrm{Al}-\mathrm{Al}$ bonds are absent in it [86]. The next isomer with the largest relative total energy, $\mathrm{Al}_{2} \mathrm{Mn}_{3}$ (XXI) $(2.2 \mathrm{~kJ} / \mathrm{mole})$, is outwardly similar to $\mathrm{Al}_{2} \mathrm{Mn}_{3}(\mathrm{XX})$ but the bond lengths $\mathrm{Al}-\mathrm{Mn}$ and $\mathrm{Mn}-\mathrm{Mn}$ as well as a distance between $\mathrm{Al} 1$ and $\mathrm{Al} 2$ in it are bit longer than in $\mathrm{Al}_{2} \mathrm{Mn}_{3}(\mathrm{XX})$, and $M_{S}$ of its ground state is 4 . The most low-energetic isomer of the given metal cluster having $M_{S}=2$, and namely $\mathrm{Al}_{2} \mathrm{Mn}_{3}(\mathrm{XIII})$, has relative total energy $29.3 \mathrm{~kJ} / \mathrm{mole}$ and, that characteristically, has the smallest number of metal-metal bonds among all $\mathrm{Al}_{2} \mathrm{Mn}_{3}$ clusters under examination (only 6). Among them, 10 isomers have $M_{S}=6$, eight have $M_{S}=4$, and seven ones have $M_{S}=2$ (Table 4$)$. As can be seen, the low-spin state is not characteristic for such metal clusters, which is quite expected from the ground state of manganese atom ( $3 d^{5} 4 s^{2}$ with five unpaired electrons). It is interesting that the most high-energetic isomer of the given metal cluster, and namely $\mathrm{Al}_{2} \mathrm{Mn}_{3}$ (XVIII), has relative total energy, equal to $149.2 \mathrm{~kJ} / \mathrm{mole}$, has the structure of trigonal pyramid as the energetically favorable isomer $\mathrm{Al}_{2} \mathrm{Mn}_{3}(\mathrm{VI})$, and exactly the same spin multiplicity of the ground state (Table 4). Most isomers of $\mathrm{Al}_{2} \mathrm{Mn}_{3}$, including the most energetically favorable $\mathrm{Al}_{2} \mathrm{Mn}_{3}$ (VI) which 
is shown in Figure $4 \mathrm{~d}$, have molecular structures resembling a trigonal pyramid. Exceptions to this include only $\mathrm{Al}_{2} \mathrm{Mn}_{3}$ (I), $\mathrm{Al}_{2} \mathrm{Mn}_{3}$ (II), $\mathrm{Al}_{2} \mathrm{Mn}_{3}$ (IX), $\mathrm{Al}_{2} \mathrm{Mn}_{3}$ (X), $\mathrm{Al}_{2} \mathrm{Mn}_{3}$ (XIII), and $\mathrm{Al}_{2} \mathrm{Mn}_{3}$ (XXIV) [86].

The next Mn $3 d$ elements of groups VIII, IX, and X of the periodic system of chemical elements, namely $\mathrm{Fe}, \mathrm{Co}$, and $\mathrm{Ni}$, however, form a much smaller number of isomers of $\mathrm{Al}_{2} \mathrm{M}_{3}$ metal clusters than $\mathrm{Mn}$. In the case of the first of them, iron, judging by the data presented in [87-89], only 8 isomers are realized, in six of which, namely $\mathrm{Al}_{2} \mathrm{Fe}_{3}$ (I) $-\mathrm{Al}_{2} \mathrm{Fe}_{3}(\mathrm{VI})$, there is a direct $\mathrm{Al}-\mathrm{Al}$ valence bond, while in the other two structures $\left[\mathrm{Al}_{2} \mathrm{Fe}_{3}\right.$ (VII) and $\mathrm{Al}_{2} \mathrm{Fe}_{3}$ (VIII)], such a bond is absent and they contain only $\mathrm{Fe}-\mathrm{Fe}$ and $\mathrm{Fe}-\mathrm{Al}$ bonds. The relative energies of the isomers of this metal cluster are presented in Table 4. It is noteworthy that, for clusters of this stoichiometric composition, the most energy-stable $\mathrm{Al}_{2} \mathrm{Fe}_{3}$ (II) structure (something like a "one-cap" tetrahedron) has multiplicity of 3 which is an intermediate between multiplicities of the high-spin and low-spin states. In the given isomer, only one $\mathrm{M}-\mathrm{M}$ bond is present (Figure 4e). The $\mathrm{Al}_{2} \mathrm{Fe}_{3}$ (III) structure closest in energy to it with a similar geometric configuration (total energy of which is $12.8 \mathrm{~kJ} / \mathrm{mol}$ higher than the total energy of the $\mathrm{Al}_{2} \mathrm{Fe}_{3}$ (II) structure) has spin multiplicity 5 . The other two structures with $M_{S}=3$, namely $\mathrm{Al}_{2} \mathrm{Fe}_{3}$ (V) and $\mathrm{Al}_{2} \mathrm{Fe}_{3}(\mathrm{VII})$, have relative total energies of 24.1 and $27.1 \mathrm{~kJ} / \mathrm{mol}$ higher than the structure of $\mathrm{Al}_{2} \mathrm{Fe}_{3}$ (II), while the two structures with $M_{S}=5$, namely, $\mathrm{Al}_{2} \mathrm{Fe}_{3}$ (VI) and $\mathrm{Al}_{2} \mathrm{Fe}_{3}$ (VIII), in terms of relative total energies ( 31.1 and $24.7 \mathrm{~kJ} / \mathrm{mol}$ ) are only slightly less stable in energy terms. The low-spin state is uncharacteristic for these clusters (Table 4), which is understandable if we take into account the presence of the iron atom in the ground state of the $3 d^{6} 4 s^{2}$ electronic configuration with four unpaired electrons.

The $\mathrm{Al}_{2} \mathrm{Co}_{3}$ metal clusters are the subject of works $[87,88]$. The total number of isomers of this metal cluster in comparison with $\mathrm{Al}_{2} \mathrm{Fe}_{3}$ turns out to be somewhat larger (9). However, their structural diversity is noticeably less than that of $\mathrm{Al}_{2} \mathrm{Fe}_{3}$ metal clusters [87,88]. Here, the direct valence bond $\mathrm{Al}-\mathrm{Al}$ is also realized in six isomers, namely, $\mathrm{Al}_{2} \mathrm{Co}_{3}$ (I)- $\mathrm{Al}_{2} \mathrm{Co}_{3}$ (III) and $\mathrm{Al}_{2} \mathrm{Co}_{3}$ (VII)- $-\mathrm{Al}_{2} \mathrm{Co}_{3}$ (IX), while in the other three isomers, namely, $\mathrm{Al}_{2} \mathrm{Co}_{3}(\mathrm{IV})-\mathrm{Al}_{2} \mathrm{Co}_{3}$ (VI), such a relationship is absent. The most stable in terms of energy among all these isomers is $\mathrm{Al}_{2} \mathrm{Co}_{3}$ (III) (Table 4), which represents a trigonal bipyramid, both of whose vertices are occupied by Co atoms (Figure 4f). The spin multiplicity of its ground state is 6 . The closest to it in energy $\left(28.9 \mathrm{~kJ} / \mathrm{mol}\right.$ higher) isomer of $\mathrm{Al}_{2} \mathrm{Co}_{3}$ (IX) also has a trigonal bipyramidal structure, but, in contrast to $\mathrm{Al}_{2} \mathrm{Co}_{3}$ (III), there are at the vertices of this bipyramid $\mathrm{Al}$ and $\mathrm{Co}$ atoms. It has the same spin multiplicity as $\mathrm{Al}_{2} \mathrm{Co}_{3}$ (III). All other isomers of the $\mathrm{Al}_{2} \mathrm{Co}_{3}$ metal cluster, in principle, are capable of self-existence, and have significantly higher total energies in comparison with $\mathrm{Al}_{2} \mathrm{Co}_{3}$ (III) and $\mathrm{Al}_{2} \mathrm{Co}_{3}$ (IX). The least stable among them is the trigonal bipyramidal $\mathrm{Al}_{2} \mathrm{Co}_{3}(\mathrm{~V})$ with two $\mathrm{Al}$ atoms at the vertices of the bipyramid, and not connected by a chemical bond. As in the case of the $\mathrm{Al}_{2} \mathrm{Fe}_{3}$ metal cluster, the low-spin state also turns out to be uncharacteristic.

The $\mathrm{Al}_{2} \mathrm{Ni}_{3}$ metal cluster is represented by the smallest number of structural isomers among all other metal clusters-only seven $[87,88]$. The direct $\mathrm{Al}-\mathrm{Al}$ valence bond in aluminum-nickel $\mathrm{Al}_{2} \mathrm{Ni}_{3}$ clusters, as well as in aluminum-iron and aluminum-cobalt analogous stoichiometric compositions, is realized again in six of its isomers. The only exception to this is the $\mathrm{Al}_{2} \mathrm{Ni}_{3}$ (VII) isomer. The relative energies of these structures are shown in Table 4 . It is noteworthy that the aforementioned isomer of $\mathrm{Al}_{2} \mathrm{Ni}_{3}$ (VII) is also the least advantageous in terms of energy, and the absolute value of its relative energy is much larger than the same indicator for the other six isomers of $\mathrm{Al}_{2} \mathrm{Ni}_{3}$. As for the most advantageous structure in terms of energy, $\mathrm{Al}_{2} \mathrm{Ni}_{3}$ (II) outwardly resembles the $\mathrm{Al}_{2} \mathrm{Co}_{3}$ (III) structure, the same trigonal bipyramid with two $\mathrm{M}$ atoms at the vertices (Figure $4 \mathrm{~g}$ ), but with spin multiplicity of the ground state equal to 3 (as in the case of the most energetically favorable structure of the iron-aluminum cluster $\mathrm{Al}_{2} \mathrm{Fe}_{3}$ (II)). The isomer nearest to it in energy, namely $\mathrm{Al}_{2} \mathrm{Ni}_{3}$ (I) with a similar geometric configuration, has a total energy that is $48.6 \mathrm{~kJ} / \mathrm{mol}$ higher than the energy of the structure $\mathrm{Al}_{2} \mathrm{Ni}_{3}$ (II). Despite the fact that the ground state of the nickel atom $\left(3 d^{8} 4 s^{2}\right)$ is characterized by the presence of only two unpaired electrons, the low-spin state for $\mathrm{Al}_{2} \mathrm{Ni}_{3}$ clusters, judging by the data of $[87,88]$, is also uncharacteristic as for aluminum-cobalt and aluminum-iron clusters of a similar stoichiometric composition. In fairness, it is worth noting that a high-spin ground state is 
characteristic for the $\mathrm{Al}_{2} \mathrm{Ni}_{3}$ metal clusters to an even lesser extent, because, as it is easily seen from the data in Table 4, the relative energies of the $\mathrm{Al}_{2} \mathrm{Ni}_{3}$ isomers having $M_{S}=5$, as a rule, significantly exceeds the relative energies of the isomers having $M_{S}=3$.

The next sequence number after the triad $(\mathrm{Fe}, \mathrm{Co}, \mathrm{Ni}) 3 d$ element, namely $\mathrm{Cu}$, forms the same number of isomers of the $\mathrm{Al}_{2} \mathrm{M}_{3}$ metal cluster as $\mathrm{Fe}$ (i.e., 8). In seven of eight of these isomers, the direct valence bond $\mathrm{Al}-\mathrm{Al}$ is realized. The only exception here is the isomer of $\mathrm{Al}_{2} \mathrm{Cu}_{3}$ (II) [89-91]. Also, in 7 out of 8 isomers, with the exception of only $\mathrm{Al}_{2} \mathrm{Cu}_{3}(\mathrm{~V})$, there is at least one $\mathrm{Cu}-\mathrm{Cu}$ bond, and $\mathrm{Al}-\mathrm{Cu}$ bonds occur in each of these isomers. The following circumstance attracts attention in that the aluminum-copper $\mathrm{Al}_{2} \mathrm{Cu}_{3}$ metal clusters have a very significant total number of metal-metal bonds: from seven to nine. In this connection, it is worth noting that in three of the eight $\mathrm{Al}_{2} \mathrm{Cu}_{3}$ isomers, the total number of metal-metal bonds is only one less than the maximum possible number of $\mathrm{Al}_{2} \mathrm{Cu}_{3}$ compounds, namely 10. The relative energies of all $\mathrm{Al}_{2} \mathrm{Cu}_{3}$ isomers are presented in Table 4 . From the data presented in Table 4, it can be seen that the most stable isomer is $\mathrm{Al}_{2} \mathrm{Cu}_{3}$ (I); the total number of metal-metal bonds in this isomer is 9 (Figure 4h). As in the majority of metal clusters having $\mathrm{Al}_{2} \mathrm{M}_{3}$ stoichiometric composition and already considered above, this isomer has not the highest spin multiplicity (4), but lower (2). However, isomers with $M_{S}=4$, namely $\mathrm{Al}_{2} \mathrm{Cu}_{3}$ (II), $\mathrm{Al}_{2} \mathrm{Cu}_{3}$ (IV) and $\mathrm{Al}_{2} \mathrm{Cu}_{3}$ (VI) as a whole, have significantly higher total energies than isomers with $M_{S}=2$ (Table 4).

In [86], a quantum chemical calculation of the $\mathrm{Al}_{2} \mathrm{Zn}_{3}$ metal daster was performed and it was shown that it can exist in 14 different isomers. Relative total energies of these isomers are presented in Table 3. As may be seen from these data, in 10 out of 14 of these isomers, the direct valence bond of $\mathrm{Al}-\mathrm{Al}$ occurs. The exceptions are the $\mathrm{Al}_{2} \mathrm{Zn}_{3}(\mathrm{X})-\mathrm{Al}_{2} \mathrm{Zn}_{3}$ (XII) and $\mathrm{Al}_{2} \mathrm{Zn}_{3}$ (XIV) isomers. Also, in the each of them, there are at least one $\mathrm{Zn}-\mathrm{Zn}$ and four $\mathrm{Al}-\mathrm{Zn}$ bonds. The isomers of $\mathrm{Al}_{2} \mathrm{Zn}_{3}$ metal clusters under examination have a very significant total number of metal-metal bonds, from seven to nine such bonds. In addition, in eight out of 14 isomers, the total number is only one less than the maximum possible number of them in $\mathrm{Al}_{2} \mathrm{M}_{3}$ (10) compounds. In this indicator, $\mathrm{Al}_{2} \mathrm{Zn}_{3}$ is superior to any other of the number of $\mathrm{Al}_{2} \mathrm{M}_{3}$ metal clusters formed by $3 d$ element atoms. However, in the most stable isomer, namely $\mathrm{Al}_{2} \mathrm{Zn}_{3}$ (I), the total number of metal-metal bonds is eight (Figure $4 \mathrm{i}$ ), i.e., nine less than occurs in most isomers of the given metal cluster. Despite of the fact that, for this metal cluster, in principle, isomers with spin multiplicities of the ground state 1,3,5, and 7 are possible, in metal clusters discovered as a result of our quantum-chemical calculation, only two values of spin multiplicity for the ground state, namely 1 and 3 , take place for $\mathrm{Al}_{2} \mathrm{Zn}_{3}$ isomers. The most stable of them, namely $\mathrm{Al}_{2} \mathrm{Zn}_{3}(\mathrm{I})$, has $M_{S}=3$. Interestingly, the same $M_{S}$ values have the next two lower-energetic isomers, namely $\mathrm{Al}_{2} \mathrm{Zn}_{3}$ (XIV) and $\mathrm{Al}_{2} \mathrm{Zn}_{3}$ (IV) having relative total energies are 3.2 and $11.0 \mathrm{~kJ} / \mathrm{mole}$, respectively. Nevertheless, the most of isomers of the cluster under examination (9 of 14) have spin singlet as ground state (Table 4). The total energy of the isomers $M_{S}=1$ as a whole is much larger than the total energy of the isomers with $M_{S}=3$. The lowest-energy of them $\mathrm{Al}_{2} \mathrm{Zn}_{3}$ (III) differs in energy from the isomer of $\mathrm{Al}_{2} \mathrm{Zn}_{3}$ (I) by 14.0, the most high-energy, $\mathrm{Al}_{2} \mathrm{Zn}_{3}$ (VIII), by $79.2 \mathrm{~kJ} / \mathrm{mole}$ [86].

The images of molecular structures of the most stable of each of $\mathrm{Al}_{2} \mathrm{M}_{3}$ metal clusters under study and geometric parameters of these structures are also presented in articles [92,93] (see Figure 4 and Table 5, respectively). With respect to the most general structural features of these five-atomic metal clusters containing two $\mathrm{Al}$ atoms and three atoms of the $3 d$ element $\mathrm{M}$ in the structural unit, it should be said that, in full accordance with theoretical expectations, for most of them, the trigonal bipyramid is most typical structure. Moreover, other geometric bodies are not uncommon here, in particular, a tetragonal pyramid and even flat polygons. Most of them are also characterized, on the one hand, by the presence of several metal-metal bonds formed by the same atom with their "neighbors," and on the other hand, by relatively high values of the lengths of these bonds, which usually exceed $200 \mathrm{pm}$. Exceptions occur only in a few cases, in particular, in the $\mathrm{Al}_{2} \mathrm{~V}_{3}$ metal cluster for bond lengths V1V2 in the isomers $\mathrm{Al}_{2} \mathrm{~V}_{3}(\mathrm{I})-\mathrm{Al}_{2} \mathrm{~V}_{3}(\mathrm{VI}), \mathrm{Al}_{2} \mathrm{~V}_{3}(\mathrm{X})$ and $\mathrm{Al}_{2} \mathrm{~V}_{3}(\mathrm{XI})$, lying in the range from $171.7 \mathrm{pm}$ [in the $\mathrm{Al}_{2} \mathrm{~V}_{3}$ (VI) structure] up to $188.1 \mathrm{pm}$ [in the structure of $\mathrm{Al}_{2} \mathrm{~V}_{3}(\mathrm{I})$ ]. On the other hand, in general, 
as expected, the $\mathrm{Al}-\mathrm{Al}$ bonds are the longest, the $\mathrm{M}-\mathrm{M}$ bonds are the shortest, while the $\mathrm{M}-\mathrm{Al}$ bond lengths occupy an intermediate position between the bond lengths formed by two aluminum atoms and two atoms $\mathrm{M}$. Further, the lengths of the $\mathrm{M}-\mathrm{M}, \mathrm{Al}-\mathrm{M}$, and $\mathrm{Al}-\mathrm{Al}$ bonds in various isomers of these metal clusters are in the ranges that, taking into account the atomic radii of $\mathrm{Al}(143 \mathrm{pm})$ and $\mathrm{M}(132 \mathrm{pm}$ (Ti), $134 \mathrm{pm}(\mathrm{V}),(\mathrm{Cr}), 127 \mathrm{pm}(\mathrm{Mn}), 126 \mathrm{pm}(\mathrm{Fe}), 125 \mathrm{pm}(\mathrm{Co}),(\mathrm{Ni}), 128 \mathrm{pm}(\mathrm{Cu})$ and $138 \mathrm{pm}(\mathrm{Zn}))$ seem to be quite natural and predictable. So, in $\mathrm{Al}_{2} \mathrm{Ti}_{3}$ isomers, the lengths of Ti-Ti bonds are in the range 210-260 pm, the lengths of $\mathrm{Al}-\mathrm{Ti}$ and $\mathrm{Al}-\mathrm{Al}$ bonds are in the ranges $252-270 \mathrm{pm}$ and 255-280 pm, and in the $\mathrm{Al}_{2} \mathrm{~V}_{3}$ isomers are in the ranges $170-275 \mathrm{pm}, 250-270 \mathrm{pm}$, and $255-270 \mathrm{pm}$ respectively. Most of the bond angles between the lines of these bonds and the torsion (dihedral) angles in the isomers of all $\mathrm{Al}_{2} \mathrm{M}_{3}$ metal clusters under consideration have values substantially less than $90^{\circ}$. The vast majority of such metal clusters either do not have symmetry elements at all, or have only one plane of symmetry. One of the few exceptions is the $\mathrm{Al}_{2} \mathrm{~V}_{3}$ (IX) metal cluster isomer which has one third-order symmetry axis, three second-order symmetry axes, three symmetry planes, and a centre of symmetry [82]. It is noteworthy that, among the most stable metal clusters of each of the $3 d$-elements considered by us and presented in Figure 4, there is not one having a similar set of symmetry elements.

Table 4. Relative energies and spin multiplicities of the ground states of various isomers of $3 d$-element metal clusters having $\mathrm{Al}_{2} \mathrm{M}_{3}$ composition ( $\mathrm{M}=\mathrm{Ti}, \mathrm{V}, \mathrm{Cr}, \mathrm{Mn}, \mathrm{Fe}, \mathrm{Co}, \mathrm{Ni}, \mathrm{Cu}, \mathrm{Zn}$ ). Roman numerals in the table are the designations of these metal clusters presented in the original works.

\begin{tabular}{|c|c|c|c|}
\hline $\begin{array}{c}\text { Structure } \\
\text { Designation }\end{array}$ & $\begin{array}{l}\text { Spin Multiplicity of } \\
\text { the Ground State }\end{array}$ & Relative Energy, kJ/mol & Ref. \\
\hline \multicolumn{4}{|c|}{$\mathrm{Al}_{2} \mathrm{Ti}_{3}$ Metal Cluster } \\
\hline $\mathrm{Al}_{2} \mathrm{Ti}_{3}(\mathrm{XIII})$ & 1 & 21.5 & \multirow{14}{*}[81,83]{} \\
\hline $\mathrm{Al}_{2} \mathrm{Ti}_{3}(\mathrm{II})$ & 1 & 24.1 & \\
\hline $\mathrm{Al}_{2} \mathrm{Ti}_{3}$ (VII) & 1 & 44.8 & \\
\hline $\mathrm{Al}_{2} \mathrm{Ti}_{3}(\mathrm{XIV})$ & 1 & 51.1 & \\
\hline $\mathrm{Al}_{2} \mathrm{Ti}_{3}$ (VIII) & 1 & 77.5 & \\
\hline $\mathrm{Al}_{2} \mathrm{Ti}_{3}(\mathrm{III})$ & 1 & 93.0 & \\
\hline $\mathrm{Al}_{2} \mathrm{Ti}_{3}(\mathrm{XII})$ & 3 & 12.6 & \\
\hline $\mathrm{Al}_{2} \mathrm{Ti}_{3}(\mathrm{X})$ & 3 & 37.0 & \\
\hline $\mathrm{Al}_{2} \mathrm{Ti}_{3}(\mathrm{VI})$ & 3 & 37.2 & \\
\hline $\mathrm{Al}_{2} \mathrm{Ti}_{3}(\mathrm{I})$ & 3 & 80.9 & \\
\hline $\mathrm{Al}_{2} \mathrm{Ti}_{3}(\mathrm{XI})$ & 5 & 0.0 & \\
\hline $\mathrm{Al}_{2} \mathrm{Ti}_{3}(\mathrm{~V})$ & 5 & 19.7 & \\
\hline $\mathrm{Al}_{2} \mathrm{Ti}_{3}$ (IV) & 5 & 60.7 & \\
\hline $\mathrm{Al}_{2} \mathrm{Ti}_{3}$ (IX) & 5 & 73.0 & \\
\hline \multicolumn{4}{|c|}{$\mathrm{Al}_{2} \mathrm{~V}_{3}$ Metal Cluster } \\
\hline $\mathrm{Al}_{2} \mathrm{~V}_{3}(\mathrm{I})$ & 2 & 25.9 & \multirow{11}{*}{82,83} \\
\hline $\mathrm{Al}_{2} \mathrm{~V}_{3}(\mathrm{IV})$ & 2 & 26.7 & \\
\hline $\mathrm{Al}_{2} \mathrm{~V}_{3}(\mathrm{VII})$ & 2 & 30.2 & \\
\hline $\mathrm{Al}_{2} \mathrm{~V}_{3}(\mathrm{~V})$ & 4 & 0.0 & \\
\hline $\mathrm{Al}_{2} \mathrm{~V}_{3}$ (II) & 4 & 2.4 & \\
\hline $\mathrm{Al}_{2} \mathrm{~V}_{3}(\mathrm{X})$ & 4 & 59.6 & \\
\hline $\mathrm{Al}_{2} \mathrm{~V}_{3}(\mathrm{VIII})$ & 4 & 71.3 & \\
\hline $\mathrm{Al}_{2} \mathrm{~V}_{3}(\mathrm{III})$ & 6 & 18.8 & \\
\hline $\mathrm{Al}_{2} \mathrm{~V}_{3}(\mathrm{VI})$ & 6 & 26.8 & \\
\hline $\mathrm{Al}_{2} \mathrm{~V}_{3}(\mathrm{XI})$ & 6 & 74.6 & \\
\hline $\mathrm{Al}_{2} \mathrm{~V}_{3}$ (IX) & 6 & 141.0 & \\
\hline \multicolumn{4}{|c|}{$\mathrm{Al}_{2} \mathrm{Cr}_{3}$ Metal Cluster } \\
\hline $\mathrm{Al}_{2} \mathrm{Cr}_{3}(\mathrm{XVIII})$ & 1 & 172.6 & \\
\hline $\mathrm{Al}_{2} \mathrm{Cr}_{3}(\mathrm{XVI})$ & 1 & 186.5 & \\
\hline $\mathrm{Al}_{2} \mathrm{Cr}_{3}(\mathrm{~V})$ & 1 & 197.2 & \\
\hline
\end{tabular}


Table 4. Cont.

\begin{tabular}{|c|c|c|c|}
\hline $\begin{array}{c}\text { Structure } \\
\text { Designation }\end{array}$ & $\begin{array}{l}\text { Spin Multiplicity of } \\
\text { the Ground State }\end{array}$ & Relative Energy, kJ/mol & Ref. \\
\hline $\mathrm{Al}_{2} \mathrm{Cr}_{3}(\mathrm{XIII})$ & 1 & 206.8 & \\
\hline $\mathrm{Al}_{2} \mathrm{Cr}_{3}(\mathrm{X})$ & 1 & 219.0 & \\
\hline $\mathrm{Al}_{2} \mathrm{Cr}_{3}(\mathrm{XIX})$ & 1 & 266.6 & \\
\hline $\mathrm{Al}_{2} \mathrm{Cr}_{3}(\mathrm{VI})$ & 1 & 287.0 & \\
\hline $\mathrm{Al}_{2} \mathrm{Cr}_{3}(\mathrm{I})$ & 1 & 396.2 & \\
\hline $\mathrm{Al}_{2} \mathrm{Cr}_{3}(\mathrm{VII})$ & 3 & 79.4 & \\
\hline $\mathrm{Al}_{2} \mathrm{Cr}_{3}$ (II) & 3 & 92.9 & \\
\hline $\mathrm{Al}_{2} \mathrm{Cr}_{3}(\mathrm{XIV})$ & 3 & 109.3 & \\
\hline $\mathrm{Al}_{2} \mathrm{Cr}_{3}(\mathrm{XI})$ & 3 & 109.6 & \\
\hline $\mathrm{Al}_{2} \mathrm{Cr}_{3}$ (III) & 5 & 0.0 & \\
\hline $\mathrm{Al}_{2} \mathrm{Cr}_{3}(\mathrm{XVII})$ & 5 & 13.1 & \\
\hline $\mathrm{Al}_{2} \mathrm{Cr}_{3}(\mathrm{VIII})$ & 5 & 19.5 & \\
\hline $\mathrm{Al}_{2} \mathrm{Cr}_{3}(\mathrm{XII})$ & 5 & 39.6 & \\
\hline $\mathrm{Al}_{2} \mathrm{Cr}_{3}(\mathrm{XX})$ & 5 & 73.4 & \\
\hline $\mathrm{Al}_{2} \mathrm{Cr}_{3}(\mathrm{XV})$ & 5 & 86.8 & \\
\hline $\mathrm{Al}_{2} \mathrm{Cr}_{3}$ (IV) & 7 & 22.9 & \\
\hline $\mathrm{Al}_{2} \mathrm{Cr}_{3}$ (IX) & 7 & 39.6 & \\
\hline \multicolumn{4}{|c|}{$\mathrm{Al}_{2} \mathrm{Mn}_{3}$ Metal Cluster } \\
\hline $\mathrm{Al}_{2} \mathrm{Mn}_{3}(\mathrm{XIII})$ & 2 & 29.3 & \multirow{25}{*}[86]{} \\
\hline $\mathrm{Al}_{2} \mathrm{Mn}_{3}(\mathrm{XVII})$ & 2 & 34.9 & \\
\hline $\mathrm{Al}_{2} \mathrm{Mn}_{3}(\mathrm{~V})$ & 2 & 47.5 & \\
\hline $\mathrm{Al}_{2} \mathrm{Mn}_{3}(\mathrm{XXII})$ & 2 & 50.5 & \\
\hline $\mathrm{Al}_{2} \mathrm{Mn}_{3}(\mathrm{XXV})$ & 2 & 80.8 & \\
\hline $\mathrm{Al}_{2} \mathrm{Mn}_{3}(\mathrm{VIII})$ & 2 & 124.0 & \\
\hline $\mathrm{Al}_{2} \mathrm{Mn}_{3}(\mathrm{XIX})$ & 2 & 129.4 & \\
\hline $\mathrm{Al}_{2} \mathrm{Mn}_{3}(\mathrm{XXI})$ & 4 & 2.2 & \\
\hline $\mathrm{Al}_{2} \mathrm{Mn}_{3}(\mathrm{XII})$ & 4 & 5.9 & \\
\hline $\mathrm{Al}_{2} \mathrm{Mn}_{3}(\mathrm{IV})$ & 4 & 11.2 & \\
\hline $\mathrm{Al}_{2} \mathrm{Mn}_{3}(\mathrm{XVI})$ & 4 & 27.0 & \\
\hline $\mathrm{Al}_{2} \mathrm{Mn}_{3}(\mathrm{VII})$ & 4 & 29.6 & \\
\hline $\mathrm{Al}_{2} \mathrm{Mn}_{3}(\mathrm{XXIV})$ & 4 & 76.1 & \\
\hline $\mathrm{Al}_{2} \mathrm{Mn}_{3}(\mathrm{II})$ & 4 & 82.2 & \\
\hline $\mathrm{Al}_{2} \mathrm{Mn}_{3}(\mathrm{X})$ & 4 & 141.7 & \\
\hline $\mathrm{Al}_{2} \mathrm{Mn}_{3}(\mathrm{VI})$ & 6 & 0.0 & \\
\hline $\mathrm{Al}_{2} \mathrm{Mn}_{3}(\mathrm{XX})$ & 6 & 1.4 & \\
\hline $\mathrm{Al}_{2} \mathrm{Mn}_{3}(\mathrm{III})$ & 6 & 19.1 & \\
\hline $\mathrm{Al}_{2} \mathrm{Mn}_{3}(\mathrm{XV})$ & 6 & 28.1 & \\
\hline $\mathrm{Al}_{2} \mathrm{Mn}_{3}(\mathrm{XI})$ & 6 & 36.6 & \\
\hline $\mathrm{Al}_{2} \mathrm{Mn}_{3}(\mathrm{XIV})$ & 6 & 42.3 & \\
\hline $\mathrm{Al}_{2} \mathrm{Mn}_{3}(\mathrm{XXIII})$ & 6 & 62.4 & \\
\hline $\mathrm{Al}_{2} \mathrm{Mn}_{3}$ (IX) & 6 & 74.6 & \\
\hline $\mathrm{Al}_{2} \mathrm{Mn}_{3}(\mathrm{I})$ & 6 & 77.2 & \\
\hline $\mathrm{Al}_{2} \mathrm{Mn}_{3}$ (XVIII) & 6 & 149.2 & \\
\hline \multicolumn{4}{|c|}{$\mathrm{Al}_{2} \mathrm{Fe}_{3}$ Metal Cluster } \\
\hline $\mathrm{Al}_{2} \mathrm{Fe}_{3}(\mathrm{I})$ & 1 & 273.7 & \multirow{8}{*}{ [87-89] } \\
\hline $\mathrm{Al}_{2} \mathrm{Fe}_{3}(\mathrm{IV})$ & 1 & 300.6 & \\
\hline $\mathrm{Al}_{2} \mathrm{Fe}_{3}(\mathrm{II})$ & 3 & 0.0 & \\
\hline $\mathrm{Al}_{2} \mathrm{Fe}_{3}(\mathrm{~V})$ & 3 & 24.1 & \\
\hline $\mathrm{Al}_{2} \mathrm{Fe}_{3}(\mathrm{VII})$ & 3 & 27.1 & \\
\hline $\mathrm{Al}_{2} \mathrm{Fe}_{3}(\mathrm{III})$ & 5 & 12.8 & \\
\hline $\mathrm{Al}_{2} \mathrm{Fe}_{3}(\mathrm{VIII})$ & 5 & 24.7 & \\
\hline $\mathrm{Al}_{2} \mathrm{Fe}_{3}(\mathrm{VI})$ & 5 & 31.1 & \\
\hline
\end{tabular}


Table 4. Cont.

\begin{tabular}{|c|c|c|c|}
\hline $\begin{array}{c}\text { Structure } \\
\text { Designation }\end{array}$ & $\begin{array}{l}\text { Spin Multiplicity of } \\
\text { the Ground State }\end{array}$ & Relative Energy, kJ/mol & Ref. \\
\hline \multicolumn{4}{|c|}{$\mathrm{Al}_{2} \mathrm{Co}_{3}$ Metal Cluster } \\
\hline $\mathrm{Al}_{2} \mathrm{Co}_{3}(\mathrm{I})$ & 2 & 56.0 & \multirow{9}{*}[87,88]{} \\
\hline $\mathrm{Al}_{2} \mathrm{Co}_{3}(\mathrm{VII})$ & 2 & 83.6 & \\
\hline $\mathrm{Al}_{2} \mathrm{Co}_{3}(\mathrm{IV})$ & 2 & 92.0 & \\
\hline $\mathrm{Al}_{2} \mathrm{Co}_{3}(\mathrm{II})$ & 4 & 86.1 & \\
\hline $\mathrm{Al}_{2} \mathrm{Co}_{3}(\mathrm{VIII})$ & 4 & 86.8 & \\
\hline $\mathrm{Al}_{2} \mathrm{Co}_{3}(\mathrm{~V})$ & 4 & 96.3 & \\
\hline $\mathrm{Al}_{2} \mathrm{Co}_{3}(\mathrm{III})$ & 6 & 0.0 & \\
\hline $\mathrm{Al}_{2} \mathrm{Co}_{3}(\mathrm{IX})$ & 6 & 28.9 & \\
\hline $\mathrm{Al}_{2} \mathrm{Co}_{3}(\mathrm{VI})$ & 6 & 73.3 & \\
\hline \multicolumn{4}{|c|}{$\mathrm{Al}_{2} \mathrm{Ni}_{3}$ Metal Cluster } \\
\hline $\mathrm{Al}_{2} \mathrm{Ni}_{3}(\mathrm{I})$ & 1 & 48.6 & \multirow{7}{*}[87,88]{} \\
\hline $\mathrm{Al}_{2} \mathrm{Ni}_{3}$ (IV) & 1 & 70.8 & \\
\hline $\mathrm{Al}_{2} \mathrm{Ni}_{3}$ (II) & 3 & 0.0 & \\
\hline $\mathrm{Al}_{2} \mathrm{Ni}_{3}(\mathrm{~V})$ & 3 & 73.1 & \\
\hline $\mathrm{Al}_{2} \mathrm{Ni}_{3}$ (III) & 5 & 102.6 & \\
\hline $\mathrm{Al}_{2} \mathrm{Ni}_{3}(\mathrm{VI})$ & 5 & 113.3 & \\
\hline $\mathrm{Al}_{2} \mathrm{Ni}_{3}(\mathrm{VII})$ & 5 & 148.4 & \\
\hline \multicolumn{4}{|c|}{$\mathrm{Al}_{2} \mathrm{Cu}_{3}$ Metal Cluster } \\
\hline $\mathrm{Al}_{2} \mathrm{Cu}_{3}(\mathrm{I})$ & 2 & 0.0 & \multirow{8}{*}{ [89-91] } \\
\hline $\mathrm{Al}_{2} \mathrm{Cu}_{3}$ (III) & 2 & 20.6 & \\
\hline $\mathrm{Al}_{2} \mathrm{Cu}_{3}(\mathrm{~V})$ & 2 & 27.0 & \\
\hline $\mathrm{Al}_{2} \mathrm{Cu}_{3}(\mathrm{VII})$ & 2 & 40.1 & \\
\hline $\mathrm{Al}_{2} \mathrm{Cu}_{3}$ (VIII) & 2 & 67.6 & \\
\hline $\mathrm{Al}_{2} \mathrm{Cu}_{3}(\mathrm{IV})$ & 4 & 136.9 & \\
\hline $\mathrm{Al}_{2} \mathrm{Cu}_{3}$ (II) & 4 & 144.1 & \\
\hline $\mathrm{Al}_{2} \mathrm{Cu}_{3}(\mathrm{VI})$ & 4 & 144.3 & \\
\hline \multicolumn{4}{|c|}{$\mathrm{Al}_{2} \mathrm{Zn}_{3}$ Metal Cluster } \\
\hline $\mathrm{Al}_{2} \mathrm{Zn}_{3}$ (III) & 1 & 14.0 & \multirow{14}{*}{ [86] } \\
\hline $\mathrm{Al}_{2} \mathrm{Zn}_{3}$ (II) & 1 & 17.7 & \\
\hline $\mathrm{Al}_{2} \mathrm{Zn}_{3}(\mathrm{XII})$ & 1 & 18.9 & \\
\hline $\mathrm{Al}_{2} \mathrm{Zn}_{3}(\mathrm{VI})$ & 1 & 22.1 & \\
\hline $\mathrm{Al}_{2} \mathrm{Zn}_{3}(\mathrm{XIII})$ & 1 & 23.8 & \\
\hline $\mathrm{Al}_{2} \mathrm{Zn}_{3}(\mathrm{XI})$ & 1 & 25.6 & \\
\hline $\mathrm{Al}_{2} \mathrm{Zn}_{3}(\mathrm{~V})$ & 1 & 29.6 & \\
\hline $\mathrm{Al}_{2} \mathrm{Zn}_{3}(\mathrm{IX})$ & 1 & 30.5 & \\
\hline $\mathrm{Al}_{2} \mathrm{Zn}_{3}$ (VIII) & 1 & 79.2 & \\
\hline $\mathrm{Al}_{2} \mathrm{Zn}_{3}(\mathrm{I})$ & 3 & 0.0 & \\
\hline $\mathrm{Al}_{2} \mathrm{Zn}_{3}(\mathrm{XIV})$ & 3 & 3.2 & \\
\hline $\mathrm{Al}_{2} \mathrm{Zn}_{3}(\mathrm{IV})$ & 3 & 11.0 & \\
\hline $\mathrm{Al}_{2} \mathrm{Zn}_{3}(\mathrm{VII})$ & 3 & 21.4 & \\
\hline $\mathrm{Al}_{2} \mathrm{Zn}_{3}(\mathrm{X})$ & 3 & 29.6 & \\
\hline
\end{tabular}

The images of molecular structures of all these pentanuclear metal clusters are presented in Supplementary Materials (Figures S4-S12).

In the articles [92,93], the thermodynamics of $\mathrm{Al}_{2} \mathrm{M}_{3}$ metal clusters formed by atoms of $3 d$ elements was considered and calculation of standard thermodynamic formation parameters $\left[\Delta_{\mathrm{f}} H^{0}(298 \mathrm{~K})\right.$, $\Delta_{\mathrm{f}} S^{0}(298 \mathrm{~K})$ and $\left(\Delta_{\mathrm{f}} G^{0}(298 \mathrm{~K})\right]$, as well as standard enthalpy, entropy and Gibbs energy of reactions of their formation from mono-atomic particles in the gas phase $\left(\Delta_{\mathrm{f}} \mathrm{H}^{0}{ }_{298}, \Delta_{\mathrm{f}} S^{0}{ }_{298}, \Delta_{\mathrm{f}} G^{0}{ }_{298}\right)$ was carried 
out. These parameters are presented in Table 6. As can be seen from these data, all $\Delta_{\mathrm{f}} H^{0}(298 \mathrm{~K})$, $\Delta_{\mathrm{f}} S^{0}(298 \mathrm{~K})$ and $\left(\Delta_{\mathrm{f}} G^{0}(298 \mathrm{~K})\right.$ values are positive, indicating the impossibility of the formation of these metal clusters from simple substances formed by the constituent elements and existing under standard conditions (i.e., from Al (crystal) and corresponding $\mathrm{M}$ (crystal)). However, for the reactions of formation of $\mathrm{Al}_{2} \mathrm{M}_{3}$ in gas phase according to general Equation (1),

$$
2 \mathrm{Al} \text { (gas) }+3 \mathrm{M} \text { (gas) } \rightarrow \mathrm{Al}_{2} \mathrm{M}_{3} \text { (gas) }
$$

another situation takes place. Each of the reactions in Equation (1) is exothermic and belong to processes whose course is due to the enthalpy factor since for any of them, the standard enthalpy is $\Delta H_{298}<0$, and $\Delta S_{298}<0$ (Table 6). In addition, heteronuclear metal clusters formed as a result of such reactions, are characterized by rather high thermal stability. In the publications [92,93], the availability of a very complex dynamics of changes in both the individual thermodynamic characteristics of the $\mathrm{Al}_{2} \mathrm{M}_{3}$ metal clusters under consideration and the thermodynamic parameters of these reactions of their formation depending on the nature of the $3 d$ element was also noted. Since for each of them, $\Delta S_{298}$ is also negative, in the simplest version, according to the Gibbs-Helmholtz equation for the isobaric process (2)

$$
\Delta G(T)=\Delta H_{298}-T \Delta S_{298}
$$

where $\Delta H_{298}$ and $\Delta S_{298}$ are the enthalpy and entropy changes as a result of the chemical process, referred to standard conditions, $T$ is the process temperature in $K$, and $\Delta G(T)$ is the dependence of the Gibbs free energy on temperature $T$ for reaction (1). Regardless of the nature of the $3 d$ element $M$, the values of both of these parameters are negative, and this fact in turn means that the given reaction is thermodynamically resolved at relatively low temperatures and forbidden at high ones. On the contrary, the reverse reaction (1) will be allowed at sufficiently high temperatures and forbidden at low ones. The minimum temperature at which this reverse reaction begins, can be considered as the temperature of the beginning thermal decomposition of the metal cluster $\left(T_{\mathrm{td}}\right)$ in the gas phase to individual $\mathrm{Al}$ and $\mathrm{M}$ atoms. As may be seen from the data presented in the Table 6, the $\Delta H_{298}$ value and, correspondingly, thermal effect of reaction (1) is very significant in all cases. Further, as it is easy to show with using Equation (2) [92,93], the temperature at which reverse reaction (1) will be possible, for almost all $\mathrm{Al}_{2} \mathrm{M}_{3}$ metal clusters (for with the exception of $\mathrm{Al}_{2} \mathrm{Zn}_{3}$ only) exceeds $1000 \mathrm{~K}$ (Table 7). Herewith, $\mathrm{Al}_{2} \mathrm{~V}_{3}$ is the most stable in this respect among all the compounds under consideration, $\mathrm{Al}_{2} \mathrm{Zn}_{3}$ is the least stable. Upon transition from Ti to $\mathrm{V}$, the temperature of the beginning of thermal decomposition increases, from $\mathrm{V}$ to $\mathrm{Cr}$ it decreases, from $\mathrm{Cr}$ to $\mathrm{Ni}$ it increases and from $\mathrm{Ni}$ to $\mathrm{Zn}$ it decreases again (Table 7). However, the dynamics of changes in the standard thermodynamic formation parameters $\left(\Delta_{\mathrm{f}} H^{0}(298 \mathrm{~K}), \Delta_{\mathrm{f}} S^{0}(298 \mathrm{~K})\right.$ and $\left.\Delta_{\mathrm{f}} \mathrm{G}^{0}(298 \mathrm{~K})\right)$ of the $\mathrm{Al}_{2} \mathrm{M}_{3}$ metal clusters under consideration is of a somewhat different and more complex character. So, for $\Delta_{\mathrm{f}} H^{0}(298 \mathrm{~K})$ и $\left(\Delta_{\mathrm{f}} G^{0}(298 \mathrm{~K})\right.$, the curves corresponding to it have a quite distinct "zigzag" shape, because both of these parameters when passing from $\mathrm{Ti}$ to $\mathrm{V}$, from $\mathrm{Cr}$ to $\mathrm{Mn}$, from $\mathrm{Fe}$ to $\mathrm{Ni}$, and decrease from $\mathrm{Cu}$ to $\mathrm{Zn}$, but increase from $\mathrm{V}$ to $\mathrm{Cr}$, from $\mathrm{Mn}$ to $\mathrm{Fe}$, and $\mathrm{Ni}$ to $\mathrm{Cu}$. However, the dynamics of the change of $\Delta_{\mathrm{f}} S^{0}(298 \mathrm{~K})$ in the Ti-Zn series are not similar to the dynamics of change as $\Delta_{\mathrm{f}} H^{0}(298 \mathrm{~K})$ and $\left(\Delta_{\mathrm{f}} G^{0}(298 \mathrm{~K})\right.$, as well as the values of the temperature of the beginning of thermal destruction $T_{\mathrm{td}}$ [92,93]. It should be noted in this connection, that there is no correlation between the parameters of the atoms of the $3 d$ elements that make up the $\mathrm{Al}_{2} \mathrm{M}_{3}$ metal clusters, which in principle can somehow be related to the thermodynamic characteristics (atomic numbers, atomic radii, ionization energies, etc.) [92,93] that are clearly visible in Figure 5 where the dependences of the thermodynamic parameters of the reaction (1) of $3 d$-element atomic number has been presented. 


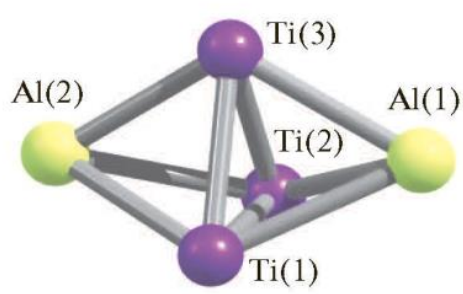

(a)

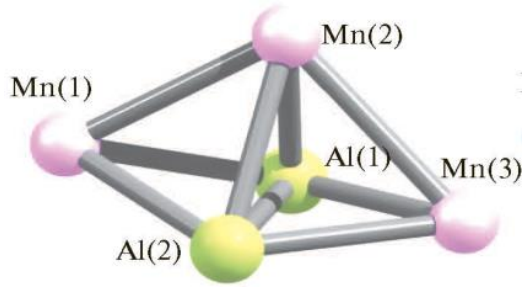

(d)

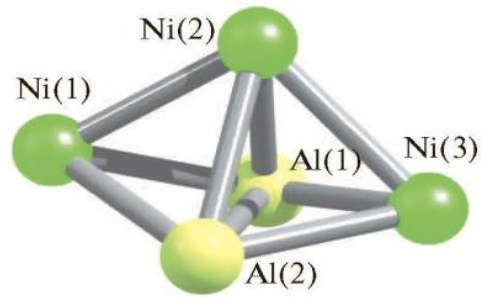

(g)

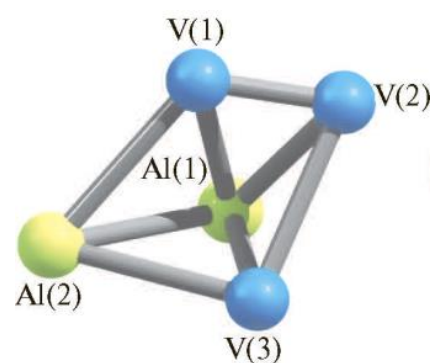

(b)

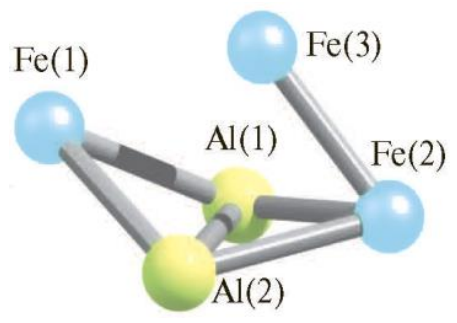

(e)

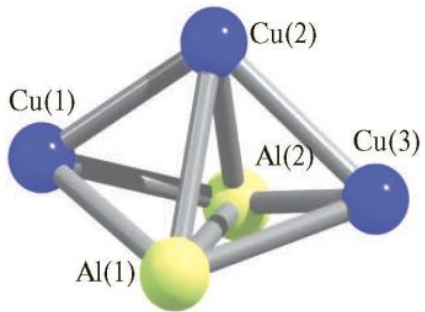

(h)

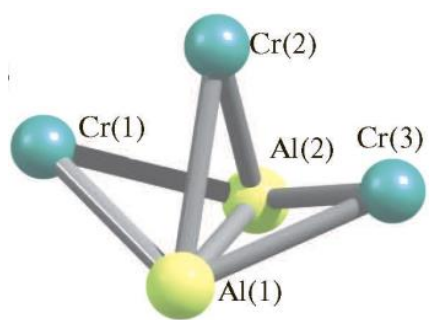

(c)

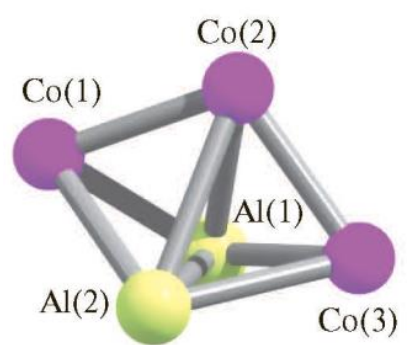

(f)

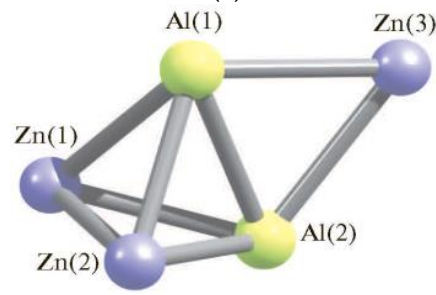

(i)

Figure 4. The images of molecular structures of most energetic stable $\mathrm{Al}_{2} \mathrm{M}_{3}$ metal clusters (M-3d-element) [92,93]: (a) - $\mathrm{Al}_{2} \mathrm{Ti}_{3},(\mathbf{b})-\mathrm{Al}_{2} \mathrm{~V}_{3},(\mathbf{c})-\mathrm{Al}_{2} \mathrm{Cr}_{3},(\mathbf{d})-\mathrm{Al}_{2} \mathrm{Mn}_{3},(\mathbf{e})-\mathrm{Al}_{2} \mathrm{Fe}_{3},(\mathbf{f})-\mathrm{Al}_{2} \mathrm{Co}_{3}$, (g) $-\mathrm{Al}_{2} \mathrm{Ni}_{3},(\mathbf{h})-\mathrm{Al}_{2} \mathrm{Cu}_{3},(\mathbf{i})-\mathrm{Al}_{2} \mathrm{Zn}_{3}$.

Table 5. Key structural parameters of most stable $\mathrm{Al}_{2} \mathrm{M}_{3}$ clusters (M-3d-element) $[92,93]$ *

\begin{tabular}{|c|c|c|c|c|c|c|c|c|c|}
\hline$\overbrace{\text { Parameter }}^{M}$ & Ti & $\mathbf{V}$ & $\mathrm{Cr}$ & Mn & Fe & Co & $\mathbf{N i}$ & $\mathrm{Cu}$ & $\mathrm{Zn}$ \\
\hline \multicolumn{10}{|c|}{ Metal-Metal Bond Lengths, pm } \\
\hline $\mathrm{Al} 1 \mathrm{Al} 2$ & 422.7 & 270.2 & 262.4 & 276.1 & 273.9 & 271.5 & 270.7 & 271.1 & 277.3 \\
\hline Al1M1 & 254.4 & 263.7 & 262.6 & 260.4 & 244.8 & 233.1 & 229.0 & 244.1 & 267.7 \\
\hline Al1M2 & 258.2 & 265.7 & 278.1 & 257.6 & 240.9 & 252.8 & 236.1 & 254.2 & 267.8 \\
\hline Al1M3 & 258.2 & 252.2 & 262.6 & 260.4 & 252.3 & 233.1 & 229.0 & 244.1 & 273.7 \\
\hline $\mathrm{A} 12 \mathrm{M} 1$ & 254.4 & 261.0 & 262.6 & 260.4 & 244.8 & 233.1 & 229.0 & 244.1 & 267.7 \\
\hline $\mathrm{A} 12 \mathrm{M} 2$ & 258.2 & 378.8 & 278.1 & 257.7 & 240.9 & 252.8 & 236.1 & 254.2 & 247.9 \\
\hline $\mathrm{Al} 2 \mathrm{M} 3$ & 258.2 & 254.4 & 262.6 & 260.4 & 252.3 & 233.1 & 229.0 & 244.1 & 273.6 \\
\hline M1M3 & 258.7 & 265.4 & 415.9 & 434.8 & 250.7 & 341.6 & 357.3 & 384.1 & 446.0 \\
\hline M2M3 & 239.0 & 253.3 & 258.1 & 281.6 & 217.6 & 215.3 & 231.1 & 243.1 & 446.1 \\
\hline M1M2 & 258.8 & 171.7 & 258.1 & 281.6 & 374.9 & 215.3 & 231.1 & 243.1 & 247.9 \\
\hline \multicolumn{10}{|c|}{ Bond Angles, deg } \\
\hline M1Al1M2 & 60.6 & 37.8 & 56.9 & 65.9 & 101.0 & 52.4 & 59.6 & 58.3 & 55.2 \\
\hline M1Al2M2 & 60.6 & 22.9 & 56.9 & 65.8 & 101.0 & 52.4 & 59.6 & 58.3 & 55.2 \\
\hline M1Al1Al2 & 33.8 & 58.5 & 60.0 & 58.0 & 56.0 & 54.4 & 53.8 & 56.3 & 58.8 \\
\hline M1Al2Al1 & 33.8 & 59.5 & 60.0 & 58.0 & 56.0 & 54.4 & 53.8 & 56.3 & 58.8 \\
\hline $\mathrm{M} 2 \mathrm{~A} 11 \mathrm{~A} 12$ & 35.6 & 90.0 & 61.9 & 57.6 & 55.4 & 57.5 & 55.0 & 57.8 & 58.8 \\
\hline M2Al2Al1 & 35.0 & 44.5 & 61.9 & 57.6 & 55.4 & 57.5 & 55.0 & 57.8 & 58.8 \\
\hline Al1M1Al2 & 112.3 & 62.0 & 59.9 & 64.0 & 68.0 & 71.2 & 72.5 & 67.4 & 62.4 \\
\hline $\mathrm{Al} 1 \mathrm{M} 2 \mathrm{Al} 2$ & 109.9 & 45.5 & 56.3 & 64.8 & 69.3 & 64.9 & 69.9 & 64.4 & 62.4 \\
\hline Al1M3Al2 & 109.9 & 64.5 & 59.9 & 64.0 & 65.7 & 68.5 & 72.5 & 67.4 & 60.9 \\
\hline
\end{tabular}


Table 5. Cont.

\begin{tabular}{cccccccccc}
\hline M & Ti & V & Cr & Mn & Fe & Co & Ni & Cu & Zn \\
Parameter & & & & & & & & & \\
M1A11M3 & 60.6 & 61.9 & 104.7 & 113.2 & 60.5 & 94.2 & 102.6 & 103.7 & 110.9 \\
M1A12M3 & 60.6 & 62.0 & 104.7 & 113.2 & 60.5 & 94.2 & 102.6 & 103.7 & 111.0 \\
M1M3M2 & 62.5 & 38.6 & 36.3 & 65.9 & 106.2 & 37.5 & 39.4 & 37.8 & 32.3 \\
M2A11M3 & 55.1 & 58.5 & 56.9 & 65.9 & 52.3 & 52.4 & 59.6 & 58.3 & 110.9 \\
M2A12M3 & 55.1 & 41.6 & 56.9 & 101.1 & 52.3 & 52.4 & 59.6 & 58.3 & 111.0 \\
M1M2M3 & 62.5 & 74.5 & 107.3 & 39.5 & 40.0 & 105.0 & 101.3 & 104.4 & 73.9 \\
\hline
\end{tabular}

* The interatomic distances and angles within which at least one of the metal-metal bonds (Al-Al, $\mathrm{Al}-\mathrm{M}$, or $\mathrm{M}-\mathrm{M})$ is absent, are shown in this table in italics.

Table 6. Standard thermodynamic parameters of formation for the most energy-stable $\mathrm{Al}_{2} \mathrm{M}_{3}$ metal clusters and the reactions of their formation from atoms of the chemical elements constituting them, in the gas phase [92,93].

\begin{tabular}{|c|c|c|c|}
\hline \multirow[b]{2}{*}{ Metal Cluster } & \multicolumn{3}{|c|}{ Standard Thermodynamic Parameters of Formation } \\
\hline & $\begin{array}{c}\Delta_{\mathrm{f}} H^{0}(298 \mathrm{~K}) \\
\mathrm{kJ} / \mathrm{mol}\end{array}$ & $\begin{array}{c}\Delta_{\mathrm{f}} S^{0}(298 \mathrm{~K}) \\
\mathrm{J} / \mathrm{mol} \cdot \mathrm{K}\end{array}$ & $\begin{array}{c}\Delta_{\mathrm{f}} G^{0}(298 \mathrm{~K}) \\
\mathrm{kJ} / \mathrm{mol}\end{array}$ \\
\hline $\mathrm{Al}_{2} \mathrm{Ti}_{3}$ & 967.4 & 429.9 & 883.5 \\
\hline $\mathrm{Al}_{2} \mathrm{~V}_{3}$ & 526.5 & 438.5 & 433.8 \\
\hline $\mathrm{Al}_{2} \mathrm{Cr}_{3}$ & 1151.1 & 417.8 & 1067.5 \\
\hline $\mathrm{Al}_{2} \mathrm{Mn}_{3}$ & 516.8 & 423.1 & 436.2 \\
\hline $\mathrm{Al}_{2} \mathrm{Fe}_{3}$ & 823.4 & 430.0 & 736.5 \\
\hline $\mathrm{Al}_{2} \mathrm{Co}_{3}$ & 817.6 & 427.6 & 733.9 \\
\hline $\mathrm{Al}_{2} \mathrm{Ni}_{3}$ & 760.9 & 430.0 & 676.3 \\
\hline $\mathrm{Al}_{2} \mathrm{Cu}_{3}$ & 812.2 & 406.9 & 737.7 \\
\hline $\mathrm{Al}_{2} \mathrm{Zn}_{3}$ & 700.1 & 445.1 & 621.7 \\
\hline \multirow[t]{2}{*}{ Metal Cluster } & \multicolumn{3}{|c|}{$\begin{array}{l}\text { Standard Thermodynamic Parameters of Reactions } \\
2 \mathrm{Al} \text { (gas) }+3 \mathrm{M} \text { (gas) } \rightarrow \mathrm{Al}_{2} \mathrm{M}_{3} \text { (gas) }\end{array}$} \\
\hline & $\Delta H_{298}, \mathrm{~kJ} / \mathrm{mol}$ & $\Delta S_{298}, \mathrm{~J} / \mathrm{mol} \cdot \mathrm{K}$ & $\Delta G_{298}, \mathrm{~kJ} / \mathrm{mol}$ \\
\hline $\mathrm{Al}_{2} \mathrm{Ti}_{3}$ & -1098.5 & -439.5 & -813.4 \\
\hline $\mathrm{Al}_{2} \mathrm{~V}_{3}$ & -1672.0 & -436.9 & -1392.1 \\
\hline $\mathrm{Al}_{2} \mathrm{Cr}_{3}$ & -694.0 & -433.6 & 407.7 \\
\hline $\mathrm{Al}_{2} \mathrm{Mn}_{3}$ & -973.4 & -426.5 & -692.2 \\
\hline $\mathrm{Al}_{2} \mathrm{Fe}_{3}$ & -1078.1 & -440.0 & -793.0 \\
\hline $\mathrm{Al}_{2} \mathrm{Co}_{3}$ & -1109.1 & -439.4 & -824.1 \\
\hline $\mathrm{Al}_{2} \mathrm{Ni}_{3}$ & -1162.8 & -445.1 & -876.0 \\
\hline $\mathrm{Al}_{2} \mathrm{Cu}_{3}$ & -858.3 & -420.8 & -578.8 \\
\hline $\mathrm{Al}_{2} \mathrm{Zn}_{3}$ & -344.6 & -366.4 & -84.3 \\
\hline
\end{tabular}

Table 7. Thermal destruction onset temperatures ( $\mathrm{Tt} d$ ) for energetically most stable Al2M3 metal clusters [92,93].

\begin{tabular}{ccc}
\hline Metal Cluster & Atomic Number of $\mathbf{M}$ & $\boldsymbol{T}_{\mathbf{t d}}, \mathbf{K}$ \\
\hline $\mathrm{Al}_{2} \mathrm{Ti}_{3}$ & 22 & 2502.2 \\
\hline $\mathrm{Al}_{2} \mathrm{~V}_{3}$ & 23 & 3826.0 \\
\hline $\mathrm{Al}_{2} \mathrm{Cr}_{3}$ & 24 & 1599.0 \\
\hline $\mathrm{Al}_{2} \mathrm{Mn}_{3}$ & 25 & 2278.6 \\
\hline $\mathrm{Al}_{2} \mathrm{Fe}_{3}$ & 26 & 2450.2 \\
\hline $\mathrm{Al}_{2} \mathrm{Co}_{3}$ & 27 & 2526.4 \\
\hline $\mathrm{Al}_{2} \mathrm{Ni}_{3}$ & 28 & 2613.0 \\
\hline $\mathrm{Al}_{2} \mathrm{Cu}_{3}$ & 29 & 2038.7 \\
\hline $\mathrm{Al}_{2} \mathrm{Zn}_{3}$ & 30 & 941.5 \\
\hline
\end{tabular}




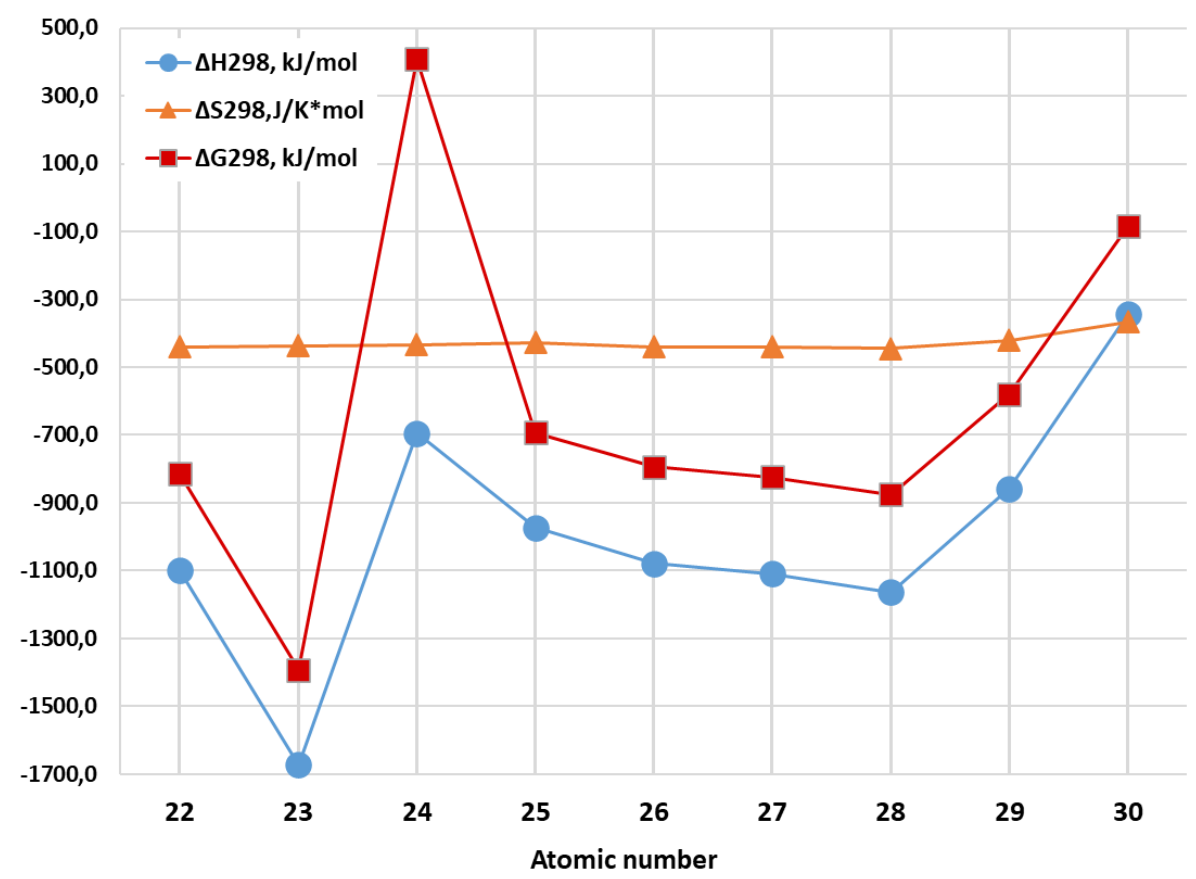

Figure 5. The dependences of the thermodynamic parameters of the reaction (1) of $3 d$-element atomic number.

It should be noted that in the current literature there is also information on the molecular structures of some $\mathrm{Al}_{2} \mathrm{M}_{3}$ metal clusters, where $\mathrm{M}$ is a $4 d$ element, namely $\mathrm{Al}_{2} \mathrm{Mo}_{3}$ and $\mathrm{Al}_{2} \mathrm{Ag}_{3}$, which is presented in the publications $[84,85]$ and $[90,91]$ cited above, respectively. However, this information is fragmentary and so far clearly insufficient for any serious generalizations.

\section{Hexanuclear (AlM) Metal Clusters}

Theoretically, for metal clusters of such a category, the existence of five types of metal clusters is admissible, namely $\mathrm{Al}_{5} \mathrm{M}, \mathrm{Al}_{4} \mathrm{M}_{2}, \mathrm{Al}_{3} \mathrm{M}_{3}, \mathrm{Al}_{2} \mathrm{M}_{4}$, and $\mathrm{AlM}_{5}$, is possible. The situation here at the moment resembles that which occurs in the case of tetranuclear (AlM) metal clusters, since until now quantum-chemical calculations have been performed for only two types of such metal clusters containing the same chemical element, namely $\mathrm{Al}_{3} \mathrm{Fe}_{3}$ and $\mathrm{Al}_{2} \mathrm{Fe}_{4}$. The results of these calculations are presented in articles [74,75,94-96]. According to them, the first of these metal clusters can exist in 20 isomers [94-96], and the second in nine $[95,96]$. The relative total energies of all these isomers are presented in Table 8. In all isomers of the first of these metal cluster, direct $\mathrm{Fe}-\mathrm{Al}$ valence bonds take place. In all of them, with the exception of only $\mathrm{Al}_{3} \mathrm{Fe}_{3}$ (XIII) and $\mathrm{Al}_{3} \mathrm{Fe}_{3}(\mathrm{XV})$, there are also at least one $\mathrm{Fe}-\mathrm{Fe}$ and $\mathrm{Al}-\mathrm{Al}$ bond. It is interesting to note in this connection that, according to the data of [94-96], namely the isomer of $\mathrm{Al}_{3} \mathrm{Fe}_{3}(\mathrm{XV})$, where $\mathrm{Al}-\mathrm{Al}$ bonds are absent, that turns out to be the most stable in energy terms. The most important parameters of the molecular structure of this isomer are presented in Table 9, and its image in Figure 6a. However, the isomer $\mathrm{Al}_{3} \mathrm{Fe}_{3}(\mathrm{XIII})$, in which, on the contrary, there are no Fe-Fe bonds but there are $\mathrm{Al}-\mathrm{Al}$ bonds, turns out to be one of the most high-energy isomers of the metal cluster under consideration (albeit not the most high-energy). Besides, the most energy-stable isomer of $\mathrm{Al}_{3} \mathrm{Fe}_{3}(\mathrm{XV})$ has a spin multiplicity of the ground state of 6, which corresponds to a high-spin state (Table 8). It is characteristic that the $\mathrm{Al}_{3} \mathrm{Fe}_{3}$ (XII) isomer which is nearest to it in energy, also has the same spin multiplicity, but its molecular structure differs significantly from the $\mathrm{Al}_{3} \mathrm{Fe}_{3}(\mathrm{XV})$ structure [94-96]. The following two structures with increasing energy, namely $\mathrm{Al}_{3} \mathrm{Fe}_{3}(\mathrm{~V})$ and $\mathrm{Al}_{3} \mathrm{Fe}_{3}$ (XIV), have a lower spin multiplicity of 4 . The most unstable isomer is $\mathrm{Al}_{3} \mathrm{Fe}_{3}$ (I), whose total energy is much higher (more than $150 \mathrm{~kJ} / \mathrm{mol}$ ) of that for the $\mathrm{Al}_{3} \mathrm{Fe}_{3}$ $(\mathrm{XV})$ isomer and for which the spin multiplicity of the ground state is 2 . Thus, it can be argued that, in general, for the isomers of $\mathrm{Al}_{3} \mathrm{Fe}_{3}$ metal cluster, the high-spin state is more characteristic. 
Table 8. Relative energies and spin multiplicities of the ground states of various isomers of metal clusters $\mathrm{Al}_{3} \mathrm{Fe}_{3}$ and $\mathrm{Al}_{2} \mathrm{Fe}_{4}$. Roman numerals in the table are the designations of these metal clusters presented in the original works.

\begin{tabular}{|c|c|c|c|}
\hline $\begin{array}{c}\text { Structure } \\
\text { Designation }\end{array}$ & $\begin{array}{l}\text { Spin Multiplicity } \\
\text { of the Ground State }\end{array}$ & Relative Energy, kJ/mol & Ref. \\
\hline \multicolumn{4}{|c|}{$\mathrm{Al}_{3} \mathrm{Fe}_{3}$ Metal Cluster } \\
\hline $\mathrm{Al}_{3} \mathrm{Fe}_{3}(\mathrm{IV})$ & 2 & 58.8 & \multirow{20}{*}{ [94-96] } \\
\hline $\mathrm{Al}_{3} \mathrm{Fe}_{3}(\mathrm{X})$ & 2 & 95.2 & \\
\hline $\mathrm{Al}_{3} \mathrm{Fe}_{3}(\mathrm{XIX})$ & 2 & 108.3 & \\
\hline $\mathrm{Al}_{3} \mathrm{Fe}_{3}(\mathrm{VII})$ & 2 & 134.5 & \\
\hline $\mathrm{Al}_{3} \mathrm{Fe}_{3}(\mathrm{XIII})$ & 2 & 137.2 & \\
\hline $\mathrm{Al}_{3} \mathrm{Fe}_{3}(\mathrm{XVI})$ & 2 & 153.7 & \\
\hline $\mathrm{Al}_{3} \mathrm{Fe}_{3}(\mathrm{I})$ & 2 & 158.3 & \\
\hline $\mathrm{Al}_{3} \mathrm{Fe}_{3}(\mathrm{~V})$ & 4 & 56.8 & \\
\hline $\mathrm{Al}_{3} \mathrm{Fe}_{3}(\mathrm{XIV})$ & 4 & 56.8 & \\
\hline $\mathrm{Al}_{3} \mathrm{Fe}_{3}$ (VIII) & 4 & 108.9 & \\
\hline $\mathrm{Al}_{3} \mathrm{Fe}_{3}(\mathrm{XI})$ & 4 & 110.1 & \\
\hline $\mathrm{Al}_{3} \mathrm{Fe}_{3}$ (II) & 4 & 130.8 & \\
\hline $\mathrm{Al}_{3} \mathrm{Fe}_{3}(\mathrm{XV})$ & 6 & 0.0 & \\
\hline $\mathrm{Al}_{3} \mathrm{Fe}_{3}(\mathrm{XII})$ & 6 & 40.8 & \\
\hline $\mathrm{Al}_{3} \mathrm{Fe}_{3}$ (IX) & 6 & 71.8 & \\
\hline $\mathrm{Al}_{3} \mathrm{Fe}_{3}(\mathrm{VI})$ & 6 & 77.3 & \\
\hline $\mathrm{Al}_{3} \mathrm{Fe}_{3}$ (III) & 6 & 78.1 & \\
\hline $\mathrm{Al}_{3} \mathrm{Fe}_{3}(\mathrm{XX})$ & 6 & 105.9 & \\
\hline $\mathrm{Al}_{3} \mathrm{Fe}_{3}(\mathrm{XVII})$ & 6 & 111.4 & \\
\hline $\mathrm{Al}_{3} \mathrm{Fe}_{3}(\mathrm{XVIII})$ & 6 & 155.4 & \\
\hline \multicolumn{4}{|c|}{$\mathrm{Al}_{2} \mathrm{Fe}_{4}$ Metal Cluster } \\
\hline $\mathrm{Al}_{2} \mathrm{Fe}_{4}(\mathrm{~V})$ & 3 & 13.0 & \multirow{9}{*}[95,96]{} \\
\hline $\mathrm{Al}_{2} \mathrm{Fe}_{4}$ (VIII) & 3 & 27.5 & \\
\hline $\mathrm{Al}_{2} \mathrm{Fe}_{4}(\mathrm{III})$ & 3 & 80.8 & \\
\hline $\mathrm{Al}_{2} \mathrm{Fe}_{4}$ (IX) & 3 & 102.8 & \\
\hline $\mathrm{Al}_{2} \mathrm{Fe}_{4}(\mathrm{VI})$ & 3 & 115.7 & \\
\hline $\mathrm{Al}_{2} \mathrm{Fe}_{4}(\mathrm{I})$ & 3 & 165.5 & \\
\hline $\mathrm{Al}_{2} \mathrm{Fe}_{4}$ (II) & 5 & 0.0 & \\
\hline $\mathrm{Al}_{2} \mathrm{Fe}_{4}$ (VII) & 5 & 25.5 & \\
\hline $\mathrm{Al}_{2} \mathrm{Fe}_{4}(\mathrm{IV})$ & 5 & 79.2 & \\
\hline
\end{tabular}

Table 9. Key structural parameters of most stable $\mathrm{Al}_{3} \mathrm{Fe}_{3}$ and $\mathrm{Al}_{2} \mathrm{Fe}_{4}$ metal clusters * [94-96].

\begin{tabular}{|c|c|c|c|}
\hline \multicolumn{2}{|c|}{$\mathrm{Al}_{3} \mathrm{Fe}_{3}$ Metal Cluster } & \multicolumn{2}{|c|}{$\mathrm{Al}_{2} \mathrm{Fe}_{4}$ Metal Cluster } \\
\hline \multicolumn{2}{|c|}{ Metal-Metal Bond Lengths, pm } & \multicolumn{2}{|c|}{ Metal-Metal Bond Lengths, pm } \\
\hline $\mathrm{Al} 1 \mathrm{Al} 2$ & 306.2 & Al1Fe1 & 242.7 \\
\hline Al1Al3 & 307.1 & $\mathrm{Al} 1 \mathrm{Fe} 2$ & 249.8 \\
\hline $\mathrm{Al} 2 \mathrm{Al} 3$ & 398.9 & Al1Fe3 & 243.8 \\
\hline Al1Fe1 & 236.4 & Al1Fe4 & 350.4 \\
\hline Al1Fe2 & 370.1 & $\mathrm{Al} 1 \mathrm{Al} 2$ & 274.7 \\
\hline Al1Fe3 & 236.3 & $\mathrm{Al} 2 \mathrm{Fe} 1$ & 242.7 \\
\hline $\mathrm{Al} 2 \mathrm{Fe} 1$ & 244.4 & $\mathrm{Al} 2 \mathrm{Fe} 2$ & 249.7 \\
\hline $\mathrm{Al} 2 \mathrm{Fe} 2$ & 242.1 & $\mathrm{Al} 2 \mathrm{Fe} 3$ & 350.4 \\
\hline $\mathrm{Al} 2 \mathrm{Fe} 3$ & 244.2 & $\mathrm{Al} 2 \mathrm{Fe} 4$ & 243.8 \\
\hline Al3Fe1 & 244.3 & $\mathrm{Fe} 2 \mathrm{Fe} 3$ & 244.1 \\
\hline $\mathrm{Al} 3 \mathrm{Fe} 2$ & 242.1 & Fe1Fe4 & 225.9 \\
\hline $\mathrm{Al} 3 \mathrm{Fe} 3$ & 244.2 & Fe1Fe3 & 225.9 \\
\hline Fe1Fe2 & 222.5 & $\mathrm{Fe} 1 \mathrm{Fe} 2$ & 329.1 \\
\hline Fe1Fe3 & 270.9 & $\mathrm{Fe} 2 \mathrm{Fe} 4$ & 244.1 \\
\hline $\mathrm{Fe} 2 \mathrm{Fe} 3$ & 222.4 & $\mathrm{Fe} 3 \mathrm{Fe} 4$ & 230.7 \\
\hline
\end{tabular}


Table 9. Cont.

\begin{tabular}{|c|c|c|c|}
\hline \multicolumn{2}{|c|}{$\mathrm{Al}_{3} \mathrm{Fe}_{3}$ Metal Cluster } & \multicolumn{2}{|c|}{$\mathrm{Al}_{2} \mathrm{Fe}_{4}$ Metal Cluster } \\
\hline \multicolumn{2}{|c|}{ Metal-Metal Bond Lengths, pm } & \multicolumn{2}{|c|}{ Metal-Metal Bond Lengths, pm } \\
\hline \multicolumn{2}{|c|}{ Bond Angles, deg } & \multicolumn{2}{|c|}{ Bond Angles, deg } \\
\hline $\mathrm{Fe} 2 \mathrm{Al} 1 \mathrm{Fe} 3$ & 35.0 & $\mathrm{Fe} 2 \mathrm{Al} 1 \mathrm{Fe} 3$ & 59.3 \\
\hline Fe1Al1Fe2 & 35.0 & Fe1Al1Fe2 & 83.9 \\
\hline $\mathrm{Fe} 1 \mathrm{Al} 2 \mathrm{Al} 3$ & 35.3 & $\mathrm{Fe} 1 \mathrm{Al} 2 \mathrm{Fe} 4$ & 55.4 \\
\hline $\mathrm{Fe} 2 \mathrm{Al} 2 \mathrm{Al} 3$ & 34.5 & $\mathrm{Fe} 2 \mathrm{Al} 2 \mathrm{Fe} 4$ & 59.3 \\
\hline $\mathrm{Al} 1 \mathrm{Al} 2 \mathrm{Fe} 2$ & 84.1 & $\mathrm{Al} 1 \mathrm{Al} 2 \mathrm{Fe} 2$ & 56.6 \\
\hline Fe2Al1Al2 & 40.6 & $\mathrm{Fe} 2 \mathrm{Al} 1 \mathrm{Al} 2$ & 56.6 \\
\hline $\mathrm{Al} 1 \mathrm{Al} 2 \mathrm{Al} 3$ & 49.5 & $\mathrm{Al} 1 \mathrm{Al} 2 \mathrm{Fe} 4$ & 84.8 \\
\hline $\mathrm{Al} 2 \mathrm{Al} 3 \mathrm{Fe} 1$ & 35.3 & $\mathrm{Al} 2 \mathrm{Fe} 4 \mathrm{Fe} 1$ & 62.1 \\
\hline $\mathrm{Al} 3 \mathrm{Fe} 1 \mathrm{Al} 2$ & 109.4 & $\mathrm{Fe} 4 \mathrm{Fe} 1 \mathrm{Al} 2$ & 62.6 \\
\hline Fe3Al1Al2 & 51.6 & Fe3Al1Al2 & 84.8 \\
\hline Fe1Al1Fe3 & 69.9 & Fe1Al1Fe3 & 55.4 \\
\hline Fe1Al1Al2 & 51.6 & Fe1Al1Al2 & 55.5 \\
\hline Al1Fe1Al2 & 79.1 & $\mathrm{Al1Fe} 1 \mathrm{Al} 2$ & 68.9 \\
\hline $\mathrm{Al} 3 \mathrm{Fe} 2 \mathrm{Fe} 3$ & 63.3 & $\mathrm{Fe} 4 \mathrm{Fe} 2 \mathrm{Fe} 3$ & 56.4 \\
\hline
\end{tabular}

* The interatomic distances and angles within which at least one of the metal-metal bonds (Al-Al, $\mathrm{Al}-\mathrm{Fe}$, or Fe-Fe) is absent, are shown in this table in italics.

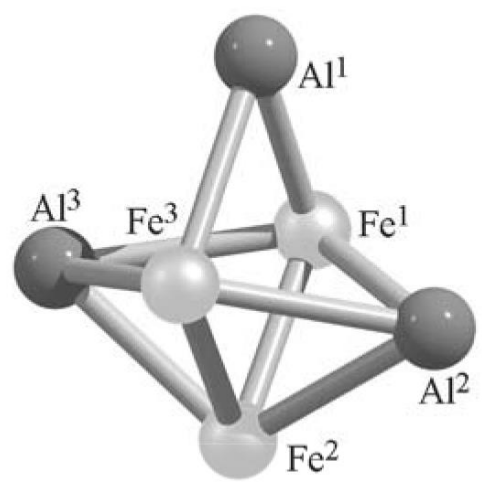

(a)

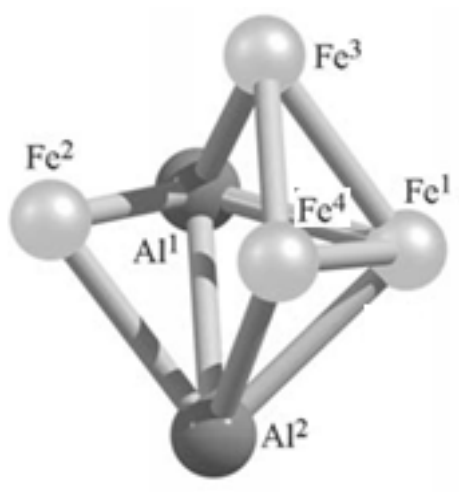

(b)

Figure 6. The images of molecular structures of most stable $\mathrm{Al}_{3} \mathrm{Fe}_{3}$ (a) and $\mathrm{Al}_{2} \mathrm{Fe}_{4}$ (b) isomers [95].

The high-spin state, judging by the data of $[95,96]$, is more characteristic in comparison with the low-spin state for $\mathrm{Al}_{2} \mathrm{Fe}_{4}$ clusters, too. In four of its 9 isomers, namely, $\mathrm{Al}_{2} \mathrm{Fe}_{4}$ (I), $\mathrm{Al}_{2} \mathrm{Fe}_{4}$ (II), $\mathrm{Al}_{2} \mathrm{Fe}_{4}$ (VIII), and $\mathrm{Al}_{2} \mathrm{Fe}_{4}$ (IX), there is a direct valence bond $\mathrm{Al}-\mathrm{Al}$, while in the other five isomers there is no such bond and there are only $\mathrm{Fe}-\mathrm{Fe}$ and $\mathrm{Fe}-\mathrm{Al}$ bonds in them. As can be seen from the data presented in Table 7, the most stable in energy terms is the isomer of $\mathrm{Al}_{2} \mathrm{Fe}_{4}$ (II), the image of the molecular structure of which is shown in Figure 6b, and its key parameters in Table 9. It is characteristic of the metal cluster under consideration that the most stable isomer of it also has the highest spin multiplicity, namely $M_{S}=5$. The isomers with a lower spin multiplicity equal to 3 generally have noticeably large total energies. At the same time, which is characteristic, among these isomers, there is not a single one the ground state of which would be a spin singlet. It is interesting that, according to the data of $[95,96]$, in principle, an almost flat $\mathrm{Al}_{2} \mathrm{Fe}_{4}$ cluster with $M_{S}=3$ (and namely, $\mathrm{Al}_{2} \mathrm{Fe}_{4}$ (I) isomer) can exist, even though it is characterized by the highest total energy compared to other compounds of the same composition, and namely $165.5 \mathrm{~kJ} / \mathrm{mol}$ (Table 8). In this regard, it is worth noting that, according to the data of [87-89], flat structures are not found among five-atom $\mathrm{Al}_{2} \mathrm{Fe}_{3}$ metal clusters.

The images of molecular structures of all these hexanuclear metal clusters are presented in Supplementary Materials (Figures S13 and S14). 
By highlighting, among other things, the general structural motifs of the isomers of hexa-nuclear (AlFe) metal clusters considered by us, we note that for most of these isomers, as well as for pentanuclear $\mathrm{Al}_{2} \mathrm{M}_{3}$, on the one hand, there are several metal-metal bonds formed by one and the same atom with its "neighbors", on the other hand, relatively high values of the lengths of these bonds, which in all cases exceed $200 \mathrm{pm}$. From the average statistical point of view, the Al-Al bonds are the longest in full accordance with theoretical expectations, the Fe-Fe bonds are the shortest, while the $\mathrm{Fe}-\mathrm{Al}$ bonds lengths occupy an intermediate position between the lengths of the bonds formed by two aluminum atoms and two iron atoms. It should be noted especially that all isomers of $\mathrm{Al}_{3} \mathrm{Fe}_{3}$ and $\mathrm{Al}_{2} \mathrm{Fe}_{4}$ metal clusters are either completely asymmetric, or have only one plane of symmetry. It is also characteristic that among the isomers of both $\mathrm{Al}_{2} \mathrm{Fe}_{4}$ and $\mathrm{Al}_{3} \mathrm{Fe}_{3}$ metal clusters, there is not one with a center of symmetry in its structure, although the structures of $\mathrm{Al}_{2} \mathrm{Fe}_{4}(\mathrm{I})$ and $\mathrm{Al}_{2} \mathrm{Fe}_{4}(\mathrm{~V})$ are rather close to those [94-96].

\section{Conclusions}

As can be seen from the above literature data, tetranuclear $\left(\mathrm{Al}_{2} \mathrm{M}_{2}\right)$, pentanuclear $\left(\mathrm{Al}_{2} \mathrm{M}_{3}\right)$, and hexa-nuclear $\left(\mathrm{Al}_{2} \mathrm{M}_{4}, \mathrm{Al}_{3} \mathrm{M}_{3}\right)$ metal clusters, containing at least two $\mathrm{Al}$ atoms and at least two $\mathrm{M}$ atoms of any of the $3 d$ elements, form a rather significant number of structural isomers that differ significantly from each other in their structural and geometric parameters and in the values of the total energy. Moreover, most isomers of these metal clusters either do not have symmetry elements at all or have only one plane or one axis of symmetry. In many of these isomers, each of the aluminum atoms contained in their composition is connected by chemical bonds with three neighboring atoms, while for the atoms of the $3 d$ element $\mathrm{M}$, this feature, to all appearances, takes place to a lesser extent. Judging by the thermodynamic parameters of the reactions of their formation in the gas phase, the most studied (AlM) metal clusters, namely pentanuclear $\mathrm{Al}_{2} \mathrm{M}_{3}$ metal clusters, are capable of independent existence, and are very stable in thermal relation (i.e., to thermal destruction). At the same time, the standard thermodynamic characteristics of compounds of a given stoichiometric composition $\left(\Delta_{\mathrm{f}} H^{0}(298 \mathrm{~K})\right.$, $\Delta_{\mathrm{f}} S^{0}(298 \mathrm{~K})$ and $\left.\Delta_{\mathrm{f}} G^{0}(298 \mathrm{~K})\right)$ very strongly depend on the nature of the $3 d$ element, and the dynamics of their change in a series Ti-Zn have a very complex and, moreover, a priori unpredictable character. Judging by the data presented in the articles published on this subject, no relationship between the total number of metal-metal bonds in the metal cluster and its relative total energy is also noted.

The $(p d)$ metal clusters considered in the given paper, in the perspective, can be used primarily for creating new composite materials and alloys based on polymetallic nanoparticles. Other possible areas of application of these and similar chemical objects include the doping of traditional alloys based on both non-ferrous and ferrous metals, metal complex catalysis, the creation of specific electrochemical systems, and semiconductor technology. The data on the specifics of the molecular structures of the metal clusters examined by us, are quite capable of serving as a starting position on the basis of which it will be possible to calculate the structures of bicomponent (aluminum $+(d$-metal)) nanoclusters, which are associations of these metal clusters and contain from several tens to several hundred atoms. Furthermore, since most of the elementary processes associated with the formation of many chemical compounds, including the formation of metal structures and their alloys, occur in fragments of matter of a nanometer range with the above number of atoms, in the future, it will be possible to solve the problems of their influence on the physical chemical properties of polymetallic compositions. For example, to solve the question of whether an alloy, an intermetallic compound, or a mechanical mixture are formed when aluminum and $d$-metal are combined. It seems highly probable that, with their application as potential so-called quantum dots, the possibilities of this technology remain far from exhausted.

Supplementary Materials: The following are available online at http://www.mdpi.com/1996-1944/13/8/1852/s1, Figure S1: Molecular structures of $\mathrm{Al}_{3} \mathrm{Fe}$ clusters, Figure S2: Molecular structures of $\mathrm{Al}_{2} \mathrm{Fe}_{2}$ clusters, Figure S3: Molecular structures of $\mathrm{AlFe}_{3}$ clusters, Figure S4: Molecular structures of $\mathrm{Al}_{2} \mathrm{Ti}_{3}$ clusters, Figure S5: Molecular structures of $\mathrm{Al}_{2} \mathrm{~V}_{3}$ clusters, Figure S6: Molecular structures of $\mathrm{Al}_{2} \mathrm{Cr}_{3}$ clusters, Figure S7: Molecular structures of 
$\mathrm{Al}_{2} \mathrm{Mn}_{3}$ clusters, Figure S8: Molecular structures of $\mathrm{Al}_{2} \mathrm{Fe}_{3}$ clusters, Figure S9: Molecular structures of $\mathrm{Al}_{2} \mathrm{Co}_{3}$ clusters, Figure S10: Molecular structures of $\mathrm{Al}_{2} \mathrm{Ni}_{3}$ clusters, Figure S11: Molecular structures of $\mathrm{Al}_{2} \mathrm{Cu}_{3}$ clusters, Figure S12: Molecular structures of $\mathrm{Al}_{2} \mathrm{Zn}_{3}$ clusters, Figure S13: Molecular structures of $\mathrm{Al}_{3} \mathrm{Fe}_{3}$ clusters, Figure S14: Molecular structures of $\mathrm{Al}_{2} \mathrm{Fe}_{4}$ clusters.

Author Contributions: Conceptualization, O.V.M.; Methodology, O.V.M. and D.V.C.; Software, D.V.C.; Validation, O.V.M. and D.V.C.; Formal Analysis, O.V.M. and D.V.C.; Investigation, O.V.M. and D.V.C.; Resources, D.V.C.; Data Curation, D.V.C.; Writing-Original Draft Preparation, O.V.M. and D.V.C.; Writing-Review \& Editing, O.V.M.; Visualization, O.V.M. and D.V.C.; Supervision, O.V.M.; Project Administration, O.V.M.; Funding Acquisition, D.V.C. All authors have read and agreed to the published version of the manuscript.

Funding: Contribution of author Chachkov D.V. was funded by the state assignment to the Federal State Institution "Scientific Research Institute for System Analysis of the Russian Academy of Sciences" No. 0065-2019-0014 for scientific research (http://www.jscc.ru).

Acknowledgments: All quantum-chemical calculations were performed at the Kazan Department of Joint Supercomputer Center of Russian Academy of Sciences - Branch of Federal Scientific Center "Scientific Research Institute for System Analysis of the RAS" that is acknowledgement for technical support.

Conflicts of Interest: The authors declare that they have no conflict of interest, financial or otherwise.

\section{References}

1. Maroun, F.; Ozanam, F.; Magnussen, O.M.; Behm, R.J. The role of atomic ensembles in the reactivity of bimetallic electrocatalysts. Science 2001, 293, 1811-1814. [CrossRef] [PubMed]

2. Derosa, P.A.; Seminario, J.M.; Balbuena, P.B. Properties of Small Bimetallic Ni-Cu Clusters. J. Phys. Chem. A 2001, 105, 7917-7925. [CrossRef]

3. Eberhardt, W. Clusters as new materials. Surf. Sci. 2002, 500, 242-270. [CrossRef]

4. Lu, Q.L.; Zhu, L.Z.; Ma, L.; Wang, G.H. Magnetic properties of $\mathrm{Co} / \mathrm{Cu}$ and $\mathrm{Co} / \mathrm{Pt}$ bimetallic clusters. Chem. Phys. Lett. 2005, 407, 176-179. [CrossRef]

5. Yuan, D.W.; Wang, Y.; Zeng, Z. Geometric, electronic, and bonding properties of Au[sub N]M (N=1-7, M=Ni, Pd, Pt) clusters. J. Chem. Phys. 2005, 122, 114310. [CrossRef]

6. Wang, X.; Cao, Z.; Lu, X.; Lin, M.; Zhang, Q. Structure and stability of binary transition-metal clusters $(\mathrm{NbCo})[s u b \mathrm{n}](\mathrm{n} \leq 5)$ : A relativistic density-functional study. J. Chem. Phys. 2005, 123, 064315. [CrossRef]

7. Barcaro, G.; Fortunelli, A.; Rossi, G.; Nita, F.; Ferrando, R. Electronic and Structural Shell Closure in AgCu and AuCu Nanoclusters. J. Phys. Chem. B 2006, 110, 23197-23203. [CrossRef]

8. Néel, N.; Kröger, J.; Berndt, R.; Wehling, T.O.; Lichtenstein, A.I.; Katsnelson, M.I. Controlling the kondo effectin $\mathrm{CoCu}_{\mathrm{n}}$ clusters atom by atom. Phys. Rev. Lett. 2008, 101, 266803. [CrossRef] [PubMed]

9. Dong, D.; Xiao-Yu, K.; Jian-Jun, G.; Ben-Xia, Z. First-principle study of $\mathrm{Au}_{\mathrm{n}} \mathrm{Fe}(\mathrm{n}=1-7)$ clusters. J. Mol. Struct. 2009, 902, 54-58.

10. Du, J.; Shen, N.; Zhu, L.; Wang, J. Emergence of noncollinear magnetic ordering in bimetallic $\mathrm{Co}_{6-\mathrm{n}} \mathrm{Mn}_{\mathrm{n}}$ clusters. J. Phys. D: Appl. Phys. 2010, 43, 015006. [CrossRef]

11. Lv, J.; Zhang, F.Q.; Jia, J.F.; Xu, X.H.; Wu, H.S. First-principles study of structural, electronic and magnetic properties of $\mathrm{Co}_{13-n} \mathrm{M}_{n}(\mathrm{n}=1,2, \mathrm{M}=\mathrm{Mn}, \mathrm{V}$ and $\mathrm{Al}$ ) clusters. J. Mol. Struct. (TheoChem) 2010, 955, 14-22. [CrossRef]

12. Kilimis, D.A.; Papageorgiou, D.G. Density functional study of small bimetallic Ag-Pd clusters. J. Mol. Struct. 2010, 939, 112-117. [CrossRef]

13. Lin, L.; Claes, P.; Gruene, P.; Meijer, G.; Fielicke, A.; Nguyen, M.T.; Lievens, P. Far-Infrared Spectra of Yttrium-Doped Gold Clusters AunY (n=1-9). ChemPhysChem 2010, 11, 1932-1943. [CrossRef] [PubMed]

14. Garbounis, D.N.; Tsipis, A.C.; Tsipis, C.A. Structural, electronic, bonding, magnetic, and optical properties of bimetallic $\left[\mathrm{Ru}_{\mathrm{n}} \mathrm{Au}_{\mathrm{m}}\right] \mathrm{O} /+(\mathrm{n}+\mathrm{m} \leq 3)$ clusters. J. Comput. Chem. 2010, 31, 2836-2852. [CrossRef] [PubMed]

15. Yang, A.; Fa, W.; Dong, I. Magnetic Properties of Transition-Metal-Doped Tubular Gold Clusters: $\mathrm{M@Au}_{24}$ ( $\mathrm{M}=\mathrm{V}, \mathrm{Cr}, \mathrm{Mn}, \mathrm{Fe}, \mathrm{Co}$, and Ni). J. Phys. Chem. A 2010, 114, 4031-4035. [CrossRef] [PubMed]

16. Venkataramanan, R.S.; Sahara, R.; Mizuseki, H.; Kawazoe, Y. Titanium-Doped Nickel Clusters TiNin $(n=$ 1-12): Geometry, Electronic, Magnetic, and Hydrogen Adsorption Properties. J. Phys. Chem. A 2010, 114, 5049-5057. [CrossRef] 
17. Wang, H.Q.; Kuang, X.Y.; Li, H.F. Density functional study of structural and electronic properties of bimetallic copper-gold clusters: Comparison with pure and doped gold clusters. Phys. Chem. Chem. Phys. 2010, 12, 5156. [CrossRef]

18. Montejano-Carrizales, J.M.; Aguilera-Granja, F.; Morán-López, J.L. Structural and magnetic properties of $\mathrm{Fe}_{\mathrm{m}} \mathrm{Y}_{\mathrm{n}}(\mathrm{m}+\mathrm{n}=7, \mathrm{Y}=\mathrm{Ru}, \mathrm{Rh}, \mathrm{Pd}$, and Pt) nanoalloys. Eur. Phys. J. D 2011, 64, 53-62. [CrossRef]

19. Jin, X.X.; Du, J.G.; Jiang, G.; Luo, X.; Wang, X.W. Geometries and electronic properties of $\mathrm{Nb}_{n} \mathrm{~V}(0, \pm 1)(\mathrm{n}=$ 1-6) clusters studied by density-functional theory. Eur. Phys. J. D 2011, 64, 323-329. [CrossRef]

20. Yang, J.X.; Guo, J.J.; Die, D. Ab initio study of $\mathrm{Au}_{\mathrm{n}} \mathrm{Ir}(\mathrm{n}=1-8)$ clusters. Comput. Theor. Chem. 2011, 963, 435-438. [CrossRef]

21. Zhao, S.; Ren, Y.; Wang, J.; Yin, W. Density functional study of NO binding on $\operatorname{small~} \operatorname{Ag}_{n} P d_{m}(n+m \leq 5)$ clusters. Comput. Theor. Chem. 2011, 964, 298-303. [CrossRef]

22. Ma, Q.M.; Xie, Z.; Wang, B.R.; Liu, Y.; You-Cheng Li, Y.C. Structure, stability and magnetic moments of the $\mathrm{Fe}_{\mathrm{n}} \mathrm{Cr}$ clusters: All-electron density functional theory investigations. Solid State Commun. 2011, 151, 806-810. [CrossRef]

23. Aguilera-Granja, F.; Longo, R.C.; Gallego, L.J.; Vega, A. Magnetic Cooperative Effects in Small Ni-Ru Clusters. J. Phys. Chem. A 2011, 115, 13950-13955. [CrossRef] [PubMed]

24. Nhatab, P.V.; Nguyen, M.T. Trends in structural, electronic and energetic properties of bimetallic vanadium-gold clusters $\mathrm{Au}_{\mathrm{n}} \mathrm{V}$ with $\mathrm{n}=1-14$. Phys. Chem. Chem. Phys. 2011, 13, 16254-16264. [CrossRef] [PubMed]

25. Lv, J.; Bai, X.; Jia, J.F.; Xu, X.H.; Wu, H.S. Structural, electronic and magnetic properties of $\mathrm{Co}_{\mathrm{n}} \mathrm{Rh}(\mathrm{n}=1-8)$ clusters from density functional calculations. Phys. B Condens. Matt. 2012, 407, 14-21. [CrossRef]

26. Hong, L.; Wang, H.; Cheng, J.; Huang, X.; Sai, L.; Zhao, J. Atomic structures and electronic properties of small Au-Ag binary clusters: Effects of size and composition. Comput. Theor. Chem. 2012, 993, 36-44. [CrossRef]

27. Shewale, V.; Deshpande, M. Structural, electronic, and magnetic properties of $\mathrm{Ni}_{\mathrm{n}} \mathrm{M}$ clusters $(\mathrm{M}=\mathrm{Hf}, \mathrm{Ta}, \mathrm{W})$ with n=1-12. Comput. Theor. Chem. 2012, 984, 128-136. [CrossRef]

28. Ding, L.P.; Kuang, X.Y.; Shao, P.; Zhao, Y.R.; Li, Y.F. A comparative study on geometries, stabilities, and electronic properties between bimetallic $\operatorname{Ag}_{n} X(X=A u, C u ; n=1-8)$ and pure silver clusters. Chin. Phys. $B$ 2012, 21, 043601. [CrossRef]

29. Yao, J.; Bin Xu, B.; Wang, Y. Ground State Structures, Electronic and Magnetic Properties of $S c_{n} F e(n=2-10)$ Clusters. Chin. J. Chem. 2012, 30, 905-913. [CrossRef]

30. Florez, E.; Mondragon, F.; Illas, F. Theoretical study of the structure and reactivity descriptors of $C u_{n} \mathrm{M}$ $(\mathrm{M}=\mathrm{Ni}, \mathrm{Pd}, \mathrm{Pt}, \mathrm{n}=1-4)$ bimetallic nanoparticles supported on $\mathrm{MgO}(001)$. Surf. Sci. 2012, 606, 1010-1018. [CrossRef]

31. Ju, W.; Yang, Z. Influence of spin-orbit coupling on electronic structures of $\mathrm{TM} @ A u_{12}(\mathrm{TM}=3 \mathrm{~d}, 4 \mathrm{~d}$, and $5 \mathrm{~d}$ atoms). Phys. Lett. A 2012, 376, 1300-1305. [CrossRef]

32. Ma, L.; Wang, J.; Hao, Y.; Wang, G. Density functional theory study of $\mathrm{FePd}_{\mathrm{n}}(\mathrm{n}=2-14)$ clusters and interactions with small molecules. Comput. Mater. Sci. 2013, 68, 166-173. [CrossRef]

33. Liu, X.; Tian, D.; Meng, C. DFT study on stability and $\mathrm{H}_{2}$ adsorption activity of bimetallic $\mathrm{Au} \mathrm{P}-{ }_{\mathrm{n}} \mathrm{Pd}_{\mathrm{n}}$ ( $\mathrm{n}=1-55)$ clusters. Chem. Phys. 2013, 415, 179-185. [CrossRef]

34. Tafoughalt, M.A.; Samah, M. Structural properties and relative stability of silver-doped gold clusters $A g A u_{n-1}$ ( $\mathrm{n}=3-13)$ : Density functional calculations. Comput. Theor. Chem. 2014, 1033, 23-30. [CrossRef]

35. Wen, J.Q.; Xia, T.; Zhou, H.; Wang, J.F. A density functional theory study of small bimetallic $\operatorname{Pd}_{\mathrm{n}} \mathrm{Al}(\mathrm{n}=1-8)$ clusters. J. Phys. Chem. Solids 2014, 75, 528-534. [CrossRef]

36. Singh, N.B.; Sarkar, U. A density functional study of chemical, magnetic and thermodynamic properties of small palladium clusters. Mol. Simul. 2014, 40, 1255-1264. [CrossRef]

37. Bouderbala, W.; Boudjahem, A.G.; Soltani, A. Geometries, stabilities, electronic and magnetic properties of small $\mathrm{Pd}_{\mathrm{n}} \operatorname{Ir}(\mathrm{n}=1-8)$ clusters from first principles calculations. Mol. Phys. 2014, 112, 1789-1798. [CrossRef]

38. Ling, W.; Dong, D.; Shi-Jian, W.; Zheng-Quan, Z. Geometrical, electronic, and magnetic properties of $\mathrm{Cu}_{n} \mathrm{Fe}$ ( $\mathrm{n}=1-12)$ clusters: A density functional study. J. Phys. Chem. Solids 2015, 76, 10-16. [CrossRef]

39. Chaves, A.S.; Rondina, G.G.; Piotrowski, M.J.; Da Silva, J.L.F. Structural formation of binary PtCu clusters: A density functional theory investigation. Comput. Mater. Sci. 2015, 98, 278-286. [CrossRef]

40. Gong, X.; Ju, W.; Li, T.; Feng, Z.; Wang, Y. Spin-orbit Splitting and Magnetism of Icosahedral M@Ag 12 Clusters ( $\mathrm{M}=3 \mathrm{~d}$ and $4 \mathrm{~d}$ atoms). J. Clust. Sci. 2015, 26, 759-773. [CrossRef] 
41. Chachkov, D.V.; Mikhailov, O.V. Molekularnye struktury poliyadernykh metalloklasterov po dannym raschyota metodom DFT. (Geterobi)tetrayadernyi klaster $\mathrm{Fe}_{2} \mathrm{Co}_{2}$. Herald Technol. Univ. 2016, 19, $20-23$.

42. Die, D.; Zheng, B.X.; Zhao, L.Q.; Zhu, Q.W.; Zhao, Z.Q. Insights into the structural, electronic and magnetic properties of V-doped copper clusters: Comparison with pure copper clusters. Sci. Rep. 2016, 6, 31978. [CrossRef] [PubMed]

43. Al-Odail, F.; Mazher, J.; Abuelela, A.M. A density functional theory study of structural, electronic and magnetic properties of small $\mathrm{Pd}_{\mathrm{n}} \mathrm{Ag}(\mathrm{n}=1-8)$ clusters. Comput. Theor. Chem. 2017, 1125, 103-111. [CrossRef]

44. Deng, M.; Xin, Z.; Yan, X.; Liu, J.; Yu, M. Structural, Electronic, and Magnetic Properties of Bimetallic $\mathrm{Ni}_{\mathrm{m}} \mathrm{Nb}_{\mathrm{n}}$ $(\mathrm{m}+\mathrm{n} \leq \mathrm{8})$ Clusters: First Principle Study. J. Supercond. Novel Magn. 2017, 30, 251-260. [CrossRef]

45. Zhang, G.; Zhai, Z.; Sheng, Y. Structural, electronic and magnetic properties of $\mathrm{Ti}_{\mathrm{n}} \mathrm{Mo}(\mathrm{n}=1-7)$ clusters. Eur. Phys. J. D 2017, 71, 9. [CrossRef]

46. Zhang, J.Y.; Lv, J. Equilibrium geometries, electronic structure and magnetic properties of ConSn $(\mathrm{n}=1-12)$ clusters from density functional calculations. Mod. Phys. Lett. B 2017, 31, 1750171. [CrossRef]

47. Datta, S.; Raychaudhuri, A.K.; Saha-Dasgupta, T. First principles study of bimetallic $\mathrm{Ni}_{13}-\mathrm{n}_{\mathrm{n}} \mathrm{Ag}_{\mathrm{n}}$ nano-clusters ( $\mathrm{n}=0-13$ ): Structural, mixing, electronic, and magnetic properties. J. Chem. Phys. 2017, 146, 164301. [CrossRef]

48. Singh, R.K.; Iwasa, T.; Taketsugu, T. Insights into geometries, stabilities, electronic structures, reactivity descriptors, and magnetic properties of bimetallic $\mathrm{Ni}_{m} \mathrm{Cu}_{n-m}(\mathrm{~m}=1,2 ; \mathrm{n}=3-13)$ clusters: Comparison with pure copper clusters. J. Comput. Chem. 2018, 39, 1878-1889. [CrossRef]

49. Ma, S.; Fei, S.; Huang, L.; Forrey, R.C.; Cheng, H. Tuning the Catalytic Activity of $\mathrm{Pd}_{\mathrm{x}} \mathrm{Ni}_{\mathrm{y}}(\mathrm{x}+\mathrm{y}=6)$ Bimetallic Clusters for Hydrogen Dissociative Chemisorption and Desorption. ACS Omega 2019, 4, 12498-12504. [CrossRef]

50. Ranjan, P.; Chakraborty, T. Structure and electronic properties of $\mathrm{Au}_{n} \mathrm{Pt}(\mathrm{n}=1-8)$ nanoalloy clusters: The density functional theory study. J. Nanopart. Res. 2020, 22, 11. [CrossRef]

51. Deshpande, M.D.; Roy, S.; Kanhere, D.G. Equilibrium geometries, electronic structure, and magnetic properties of $\mathrm{Ni}_{\mathrm{n}} \mathrm{Sn}$ clusters ( $\left.\mathrm{n}=1-12\right)$. Phys. Rev. B 2007, 76, 195423. [CrossRef]

52. Chen, X.; Deng, K.; Liu, Y.; Tang, C.; Yuan, Y.; Tan, W.; Wang, X. The geometric, optical, and magnetic properties of the endohedral stannaspherenes M@Sn[sub 12] (M=Ti, V, Cr, Mn, Fe, Co, Ni). J. Chem. Phys. 2008, 129, 094301. [CrossRef] [PubMed]

53. Tang, C.; Liu, M.; Zhu, W.; Deng, K. Probing the geometric, optical, and magnetic properties of 3d transition-metal endohedral $\mathrm{Ge}_{12} \mathrm{M}(\mathrm{M}=\mathrm{Sc}-\mathrm{Ni})$ clusters. Comput. Theor. Chem. 2011, 969, 56-60. [CrossRef]

54. Rohrmann, U.; Schäfer, R. Stern-Gerlach Experiments on Fe@Sn 12 : Magnetic Response of a Jahn-Teller Distorted Endohedrally Doped Molecular Cage Cluster. J. Phys. Chem. C 2015, 119, 10958-10961. [CrossRef]

55. Shewale, V.H.; Deshpande, M.D.; Kanhere, D.G. Structures, energetics and magnetic properties of $(\mathrm{NiSn})_{\mathrm{n}}$ clusters with $\mathrm{n}=1-6$. Pramana 2009, 73, 699-710. [CrossRef]

56. Jaiswal, S.; Kumar, V. Growth behavior and electronic structure of neutral and anion $\mathrm{ZrGe}_{\mathrm{n}}(\mathrm{n}=1-21)$ clusters. Comput. Theor. Chem. 2016, 1075, 87-97. [CrossRef]

57. Sosa-Hernández, E.M.; Montejano-Carrizales, J.M.; Alvarado-Leyva, P.G. Global Minimum Structures, Stability and Electronic Properties of Small NiX $\mathrm{Sn}_{Y}(\mathrm{X}+\mathrm{Y} \leq 5)$ Bimetallic Clusters; a DFT Study. Eur. Phys. J. D 2016, 70, 208. [CrossRef]

58. Zhao, G.; Zhang, J.; Jing, Q.; Luo, Y.; Wang, Y. A density functional study of Y[sub n]Al (n=1-14) clusters. J. Chem. Phys. 2007, 127, 234312. [CrossRef]

59. Tian, F.Y.; Jing, Q.; Wang, Y.X. Structure, stability, and magnetism of $\mathrm{Sc}_{\mathrm{n}} \mathrm{Al}(\mathrm{n}=1-8,12)$ clusters: Density-functional theory investigations. Phys. Rev. A 2008, 77, 013202. [CrossRef]

60. Wang, M.; Qiu, G.; Huang, X.; Du, Z.; Li, Y. Study of the size-dependent properties of $\mathrm{Sc}_{\mathrm{n}} \mathrm{Al}(\mathrm{n}=1-14)$ clusters by density-functional theory. J. Phys. Condens. Matter. 2009, 21, 046004. [CrossRef]

61. Du, J.; Sun, X.; Jiang, G. Structures, chemical bonding, magnetisms of small Al-doped zirconium clusters. Phys. Lett. A 2010, 374, 854-860. [CrossRef]

62. Hua, Y.; Liu, Y.; Jiang, G.; Du, J.; Chen, J. Geometric Transition and Electronic Properties of Titanium-Doped Aluminum Clusters: $\mathrm{Al}_{\mathrm{n}} \mathrm{Ti}(\mathrm{n}=2-24)$. J. Phys. Chem. A 2013, 117, 2590-2597. [CrossRef] [PubMed]

63. Rusina, G.G.; Borisova, S.D.; Chulkov, E.V. Structure and atomic vibrations in bimetallic $\mathrm{Ni}_{13}-\mathrm{n} \mathrm{Al}_{\mathrm{n}}$ clusters. JETP Letters 2015, 101, 474-480. [CrossRef] 
64. Schaefer, A.; Horn, H.; Ahlrichs, R. Fully optimized contracted Gaussian basis sets for atoms Li to Kr. J. Chem. Phys. 1992, 97, 2571-2577. [CrossRef]

65. Weigend, F.; Ahlrichs, R. Balanced basis sets of split valence, triple zeta valence and quadruple zeta valence quality for H to Rn: Design and assessment of accuracy. Phys. Chem. Chem. Phys. 2005, 7, 3297-3305. [CrossRef]

66. Hoe, W.M.; Cohen, A.; Handy, N.C. Assessment of a new local exchange functional OPTX. Chem. Phys. Lett. 2001, 341, 319-328. [CrossRef]

67. Perdew, J.P.; Burke, K.; Ernzerhof, M. Generalized Gradient Approximation Made Simple. Phys. Rev. Lett. 1997, 78, 1396. [CrossRef]

68. Frisch, M.J.; Trucks, G.W.; Schlegel, H.B.; Scuseria, G.E.; Robb, M.A.; Cheeseman, J.R.; Scalmani, G.; Barone, V.; Mennucci, B.; Petersson, G.A.; et al. Gaussian 09, Revision A.01; Gaussian, Inc.: Wallingford, CT, USA, 2009.

69. Paulsen, H.; Duelund, L.; Winkler, H.; Toftlund, H.; Trautwein, A.X. Free Energy of Spin-Crossover Complexes Calculated with Density Functional Methods. Inorg. Chem. 2001, 40, 2201-2203. [CrossRef]

70. Swart, M.; Groenhof, A.R.; Ehlers, A.W.; Lammertsma, K. Validation of Exchange-Correlation Functionals for Spin States of Iron Complexes. J. Phys. Chem. A 2004, 108, 5479-5483. [CrossRef]

71. Swart, M.; Ehlers, A.W.; Lammertsma, K. Performance of the OPBE exchange-correlation functional. Mol. Phys. 2004, 102, 2467-2474. [CrossRef]

72. Swart, M. Metal-ligand bonding in metallocenes: Differentiation between spin state, electrostatic and covalent bonding. Inorg. Chim. Acta 2007, 360, 179-189. [CrossRef]

73. Chachkov, D.V.; Mikhailov, O.V. Molekulyarnye struktury poliyadernykh metalloklasterov po dannym raschyota metodom DFT. (Geterobi)tetrayadernyi klaster AlFe 3 . Herald Technol. Univ. 2016, 19, 18-21.

74. Mikhailov, O.V.; Chachkov, D.V. Models of Molecular Structures of Aluminum-Iron Clusters $\mathrm{AlFe}_{3}, \mathrm{Al}_{2} \mathrm{Fe}_{3}$, and $\mathrm{Al}_{2} \mathrm{Fe}_{4}$ according to Quantum-Chemical DFT Calculations. Russ. J. Inorg. Chem. 2017, 62, 336-343. [CrossRef]

75. Mikhailov, O.V.; Chachkov, D.V. Modeli molekularnylh struktur alyuminii-zheleznykh klasterov $\mathrm{AlFe}_{3}$, $\mathrm{Al}_{2} \mathrm{Fe}_{3}$ i $\mathrm{Al}_{2} \mathrm{Fe}_{4}$ po dannym kvantovo-khimicheskogo rascheta metodom DFT. Zh. Neorg. Khim. 2017, 62, 321-329.

76. Mikhailov, O.V.; Chachkov, D.V. Molecular Structures of Tetranuclear (Al, Fe) Metal Clusters. Glass Phys. Chem. 2018, 44, 339-345. [CrossRef]

77. Mikhailov, O.V.; Chachkov, D.V. Molekularnye struktury tetrayadernykh (Al, Fe) metalloklasterov. Fizika $i$ Khimiya Stekla 2018, 44, 408-415.

78. Chachkov, D.V.; Mikhailov, O.V. Molekulyarnye struktury poliyadernykh metalloklasterov po dannym raschyota metodom DFT. (Geterotri)tetrayadernyi klaster $\mathrm{Al}_{2} \mathrm{FeCo}$. Herald Technol. Univ. 2016, 19, $30-32$.

79. Mikhailov, O.V.; Chachkov, D.V. Quantum Chemical Calculation of Molecular Structures of $\mathrm{Al}_{2} \mathrm{Fe}_{2}$ and $\mathrm{Al}_{2} \mathrm{FeCo}$ Tetranuclear Metalloclusters. Glass Phys. Chem. 2017, 43, 597-604. [CrossRef]

80. Mikhailov, O.V.; Chachkov, D.V. Kvantovo-khimicheskii raschyot molekularnykh struktur tetrayadernykh metalloklasterov $\mathrm{Al}_{2} \mathrm{Fe}_{2}$ i $\mathrm{Al}_{2} \mathrm{FeCo}$. Fizika i Khimiya Stekla 2017, 43, 632-639.

81. Chachkov, D.V.; Mikhailov, O.V. Molekulyarnye struktury poliyadernykh metalloklasterov po dannym raschyota metodom DFT. (Geterobi)pentayadernyi klaster $\mathrm{Al}_{2} \mathrm{Ti}_{3}$. Herald Technol. Univ. 2016, 19, 5-8.

82. Chachkov, D.V.; Mikhailov, O.V. Molekulyarnye struktury poliyadernykh metalloklasterov po dannym raschyota metodom DFT. (Geterobi)pentayadernyi klaster $\mathrm{Al}_{2} \mathrm{~V}_{3}$. Herald Technol. Univ. 2016, 19, $12-15$.

83. Mikhailov, O.V.; Chachkov, D.V. Molecular structure models of $\mathrm{Al}_{2} \mathrm{Ti}_{3}$ and $\mathrm{Al}_{2} \mathrm{~V}_{3}$ clusters according to DFT quantum-chemical calculation. Eur. Chem. Bull. 2020, 9, 62-68. [CrossRef]

84. Mikhailov, O.V.; Chachkov, D.V. Models of Molecular Structures of $\mathrm{Al}_{2} \mathrm{Cr}_{3}$ and $\mathrm{Al}_{2} \mathrm{Mo}_{3} \mathrm{Metal}_{\text {Clusters }}$ according to Density Functional Theory Calculations. Russ. J. Inorg. Chem. 2018, 63, 786-799. [CrossRef]

85. Mikhailov, O.V.; Chachkov, D.V. Modeli molekularnykh struktur metalloklasterov $\mathrm{Al}_{2} \mathrm{Cr}_{3}$ i $\mathrm{Al}_{2} \mathrm{Mo}_{3}$ po dannym metoda funktsionala plotnosti. Zh. Neorg. Khim. 2018, 63, 750-763.

86. Mikhailov, O.V.; Chachkov, D.V. Quantum-chemical calculation of molecular structures of $\mathrm{Al}_{2} \mathrm{Mn}_{3}$ and $\mathrm{Al}_{2} \mathrm{Zn}_{3}$ clusters by using DFT method. Struct. Chem. 2019, 30, 1289-1299. [CrossRef]

87. Mikhailov, O.V.; Chachkov, D.V. Models of Molecular Structure of Heteronuclear Clusters $\mathrm{Al}_{2} \mathrm{Fe}_{3}, \mathrm{Al}_{2} \mathrm{Co}_{3}$, and $\mathrm{Al}_{2} \mathrm{Ni}_{3}$ According to the Data of Quantum-Chemical Density Functional Simulation. Russ. J. Gen. Chem. 2016, 86, 1991-1998. [CrossRef] 
88. Mikhailov, O.V.; Chachkov, D.V. Modeli molekularnykh struktur geteroyadernykh klasterov $\mathrm{Al}_{2} \mathrm{Fe}_{3}, \mathrm{Al}_{2} \mathrm{Co}_{3}$ и $\mathrm{Al}_{2} \mathrm{Ni}_{3}$ po dannym kvantovo-khimicheskogo raschyota po metody funktsionala plotnosti. Zh. Obshch. Khim. 2016, 86, 1419-1428.

89. Mikhailov, O.V.; Chachkov, D.V. DFT calculation of molecular structures of $\mathrm{Al}_{2} \mathrm{Fe}_{3}$ and $\mathrm{Al}_{2} \mathrm{Cu}_{3}$ heterobinuclear clusters. Struct. Chem. 2018, 29, 1543-1549. [CrossRef]

90. Chachkov, D.V.; Mikhailov, O.V. DFT Quantum Chemical Calculation of the Molecular Structures of the Metal Clusters $\mathrm{Al}_{2} \mathrm{Cu}_{3}$ and $\mathrm{Al}_{2} \mathrm{Ag}_{3}$. Russ. J. Inorg. Chem. 2019, 64, 79-87. [CrossRef]

91. Chachkov, D.V.; Mikhailov, O.V. DFT Kvantovo-khimicheskii raschyot molekularnykh struktur metalloklasterov $\mathrm{Al}_{2} \mathrm{Cu}_{3}$ i $\mathrm{Al}_{2} \mathrm{Ag}_{3}$ metodom DFT. Zh. Neorg. Khim. 2019, 64, 63-71.

92. Mikhailov, O.V.; Chachkov, D.V. Thermodynamics of $\mathrm{Al}_{2} \mathrm{M}_{3}$ Metal Clusters $(\mathrm{M}=3 \mathrm{~d}$-element) in the framework of quantum-chemical modeling by DFT method. Russ. J. Inorg. Chem. 2020, 65, 646-649.

93. Mikhailov, O.V.; Chachkov, D.V. Termodinamika metalloklasterov $\mathrm{Al}_{2} \mathrm{M}_{3}(\mathrm{M}=3 \mathrm{~d}$-element) v ramkakh kvantovo-khimicheskogo modelirovaniya metodom DFT. Zh. Neorg. Khim. 2020, 65, 598-602.

94. Chachkov, D.V.; Mikhailov, O.V. Molekulyarnye struktury poliyadernykh metalloklasterov po dannym raschyota metodom DFT. (Geterobi)hexayadernyi klaster $\mathrm{Al}_{3} \mathrm{Fe}_{3}$. Herald Technol. Univ. 2016, 19, 89-93.

95. Chachkov, D.V.; Mikhailov, O.V. Molecular Structure of Hexatomic Heteronuclear (AlFe) Metal Clusters as Determined by the DFT Quantum-Chemical Calculation. Russ. J. Gen. Chem. 2017, 87, 670-678. [CrossRef]

96. Chachkov, D.V.; Mikhailov, O.V. Molekulyarnye struktury shestiatomnykh geteroyadernykh (AlFe) metalloklasterov po dannym po dannym kvantovo-khimicheskogo raschyota metodom DFT. Zh. Obshch. Khim. 2017, 87, 535-543.

(C) 2020 by the authors. Licensee MDPI, Basel, Switzerland. This article is an open access article distributed under the terms and conditions of the Creative Commons Attribution (CC BY) license (http://creativecommons.org/licenses/by/4.0/). 